\title{
Different Modes of Hydrogen Peroxide Action During Seed Germination
}

\author{
Łukasz Wojtyla*, Katarzyna Lechowska, Szymon Kubala† and Małgorzata Garnczarska \\ Department of Plant Physiology, Institute of Experimental Biology, Adam Mickiewicz University in Poznan, Poznan, Poland
}

Hydrogen peroxide was initially recognized as a toxic molecule that causes damage at different levels of cell organization and thus losses in cell viability. From the 1990s, the role of hydrogen peroxide as a signaling molecule in plants has also been discussed. The beneficial role of $\mathrm{H}_{2} \mathrm{O}_{2}$ as a central hub integrating signaling network in response to biotic and abiotic stress and during developmental processes is now well established.

OPEN ACCESS

Edited by:

Naser A. Anjum,

University of Aveiro, Portugal

Reviewed by:

Lam-Son Tran,

RIKEN Center for Sustainable

Resource Science, Japan

Abdul Wahid,

University of Agriculture Faisalabad,

Pakistan

*Correspondence:

Łukasz Wojtyla

lukasz.wojtyla@amu.edu.pl

${ }^{{ } \text {Present address: }}$

Szymon Kubala,

Department of Protein Biosynthesis,

Institute of Biochemistry

and Biophysics, Polish Academy

of Sciences, Warsaw, Poland

Specialty section:

This article was submitted to Plant Physiology,

a section of the journal

Frontiers in Plant Science

Received: 05 November 2015

Accepted: 14 January 2016

Published: 04 February 2016

Citation:

Wojtyla Ł, Lechowska K, Kubala S and Garnczarska M (2016) Different Modes of Hydrogen Peroxide Action

During Seed Germination.

Front. Plant Sci. 7:66.

doi: 10.3389/fpls.2016.00066
Seed germination is the most pivotal phase of the plant life cycle, affecting plant growth and productivity. The function of hydrogen peroxide in seed germination and seed aging has been illustrated in numerous studies; however, the exact role of this molecule remains unknown. This review evaluates evidence that shows that $\mathrm{H}_{2} \mathrm{O}_{2}$ functions as a signaling molecule in seed physiology in accordance with the known biology and biochemistry of $\mathrm{H}_{2} \mathrm{O}_{2}$. The importance of crosstalk between hydrogen peroxide and a number of signaling molecules, including plant phytohormones such as abscisic acid, gibberellins, and ethylene, and reactive molecules such as nitric oxide and hydrogen sulfide acting on cell communication and signaling during seed germination, is highlighted. The current study also focuses on the detrimental effects of $\mathrm{H}_{2} \mathrm{O}_{2}$ on seed biology, i.e., seed aging that leads to a loss of germination efficiency. The dual nature of hydrogen peroxide as a toxic molecule on one hand and as a signal molecule on the other is made possible through the precise spatial and temporal control of its production and degradation. Levels of hydrogen peroxide in germinating seeds and young seedlings can be modulated via pre-sowing seed priming/conditioning. This rather simple method is shown to be a valuable tool for improving seed quality and for enhancing seed stress tolerance during post-priming germination. In this review, we outline how seed priming/conditioning affects the integrative role of hydrogen peroxide in seed germination and aging.

Keywords: dormancy, germination, hydrogen peroxide, phytohormone, priming, reactive oxygen species, seed, signaling molecule

\section{INTRODUCTION}

Hydrogen peroxide $\left(\mathrm{H}_{2} \mathrm{O}_{2}\right)$ is a reactive molecule that plays a dual role in plant physiological and developmental processes and in resisting stress. The mutual relationship between positive and negative functions performed by $\mathrm{H}_{2} \mathrm{O}_{2}$ in biological systems depends on the $\mathrm{H}_{2} \mathrm{O}_{2}$ concentration, on physiological conditions, and on the specificities of processes affected by $\mathrm{H}_{2} \mathrm{O}_{2}$. Thus, it is challenging to clearly distinguish between beneficial (signaling) and deleterious (causing damage) 
roles played by $\mathrm{H}_{2} \mathrm{O}_{2}$. It is also a considerable challenge to separate the roles of $\mathrm{H}_{2} \mathrm{O}_{2}$ from those of other reactive oxygen species (ROS) such as superoxide anion $\left(\mathrm{O}_{2}{ }^{\bullet-}\right)$ and hydroxyl radical $\left({ }^{\bullet} \mathrm{OH}\right)$, which may coexist and be converted into one another through spontaneous and catalyzed reactions. In this review, we focus on functions performed by $\mathrm{H}_{2} \mathrm{O}_{2}$ during seed germination and their modulation as a result of pre-sowing seed priming.

Seed germination is one of the most important stages of the plant life cycle. The efficient progression of germination determines the nature of seedling establishment and the proper development of mature plants. Germination is a very complex process that begins with water uptake and involves events associated with the transition of a quiescent dry seed to a metabolically active state. The emergence of the embryonic axis through structures surrounding the embryo is considered to be a final stage of germination (Weitbrecht et al., 2011; Bewley et al., 2013). Key processes associated with germination involve the reactivation of metabolism, the resumption of cellular respiration, the biogenesis of mitochondria, DNA repair, the translation and/or degradation of stored mRNAs, the transcription and translation of new mRNAs, and the onset of reserve mobilization (Bentsik and Koornneef, 2008; Nonogaki et al., 2010; Bewley et al., 2013).

These biochemical and cellular events triggered by water uptake are accompanied by the generation of ROS (especially $\mathrm{H}_{2} \mathrm{O}_{2}$ ) as shown in Figure 1 (El-Maarouf-Bouteau and Bailly, 2008). The accumulation of $\mathrm{H}_{2} \mathrm{O}_{2}$ and of other ROS has been identified in seed physiology during imbibition and during early stages of germination, mainly as a result of a pronounced increase in their intracellular and extracellular production (Schopfer et al., 2001; Kranner et al., 2010; Zhang et al., 2014b; Kubala et al., 2015b). While ROS are also produced in dry seeds, they (or at least $\mathrm{H}_{2} \mathrm{O}_{2}$ ) fulfill their functions as cellular messengers or toxic molecules, mainly when seeds become hydrated, i.e., during imbibition and germination (Bailly et al., 2008). A comparative study on water uptake, on its distribution and on associated free radical and $\mathrm{H}_{2} \mathrm{O}_{2}$ production was conducted in reference to pea imbibition and germination (Pisum sativum) seeds (Wojtyla et al., 2006). ROS are often recognized as a main source of seed deterioration associated with a loss of seed vigor and as a repercussion of aging (Kumar et al., 2015). At a hydrated state, an intense increase in respiratory activity spurs superoxide anion production during electron leakage from the mitochondrial electron transport chain followed by dismutation to $\mathrm{H}_{2} \mathrm{O}_{2}$.

Other sources of ROS are NADPH oxidases of the plasma membrane, also known as respiratory burst oxidase homologs (Rboh), and extracellular peroxidases, which can produce superoxide radicals that are subsequently converted to $\mathrm{H}_{2} \mathrm{O}_{2}$. Glyoxysomes also participate in the intense production of $\mathrm{H}_{2} \mathrm{O}_{2}$ via the $\beta$-oxidation pathway during oil reserve mobilization (Bailly, 2004; El-Maarouf-Bouteau and Bailly, 2008). Among ROS, $\mathrm{H}_{2} \mathrm{O}_{2}$, a long-lived ROS that can diffuse easily through membranes and that can reach targets far from production sites, is recognized as an important signaling molecule (Møller et al., 2007). However, $\mathrm{H}_{2} \mathrm{O}_{2}$ has strong oxidizing capacities that render it capable of interacting with most biomolecules (including nucleic acids, proteins, and lipids), thus resulting in oxidative stress that causes cellular damage. Lipid peroxidation is one of the most widely documented toxic effects of $\mathrm{H}_{2} \mathrm{O}_{2}$ on cellular components and biological molecules. Lipid peroxidation affects polyunsaturated fatty acids (PUFAs) found in cell membranes or reserve lipids. Nucleic acids (DNA, RNA) and proteins are also potential targets of oxidation by $\mathrm{H}_{2} \mathrm{O}_{2}$ (El-Maarouf-Bouteau and Bailly, 2008). Oxidative DNA damage induced by $\mathrm{H}_{2} \mathrm{O}_{2}$ leads to the accumulation of 7,8-dihydro-8-oxoguanine (8-oxo-dG), which has been shown to cause the accumulation of doublestrand breaks in genome and deleterious effects on cell viability (Pommier et al., 2003).

DNA oxidation by ROS is considered a main source of DNA damage during seed storage and germination. Recently published data have shown that mRNA is much more sensitive to oxidative damage than DNA, mainly due to its cellular localization, single stranded structure and lack of repair mechanisms (Kong and Lin, 2010). As in DNA, the most frequently oxidized base in RNA is guanine, from which oxidation leads to the accumulation of 8-hydroxyguanosine (8-OHG). Oxidative damage to mRNA results in the inhibition of protein synthesis and in protein degradation (El-Maarouf-Bouteau et al., 2013; Chmielowska-Bąk et al., 2015). Protein oxidation can alter protein functions as a result of modifications made to their enzymatic and binding properties (Davies, 2005). Indeed, $\mathrm{H}_{2} \mathrm{O}_{2}$ accumulation and associated oxidative damages together with a decline in antioxidant mechanisms can be regarded as a source of stress that may affect the successful completion of germination. However, $\mathrm{H}_{2} \mathrm{O}_{2}$ is also regarded as a signaling hub for the regulation of seed dormancy and germination, and the precise regulation of $\mathrm{H}_{2} \mathrm{O}_{2}$ accumulation by cell antioxidant machinery is crucial to achieve a balance between oxidative signaling that promotes germination and oxidative damage that prevents or delays germination. These findings were clearly summarized and presented as the principle of the "oxidative window" for germination by Bailly et al. (2008). According to this hypothesis, both lower and higher levels of ROS impair seed germination, and this is only possible within a critical range of concentrations.

Recent evidence shows that the selective oxidation of proteins and mRNAs can act as a positive regulator of seed germination (Job et al., 2005; Oracz et al., 2007; Barba-Espín et al., 2011; Bazin et al., 2011). Bazin et al. (2011) showed that approximately 24 stored mRNAs undergo oxidation during sunflower (Helianthus annuus) after ripening. Most of these transcripts correspond to proteins involved in cellular signaling. Moreover, the same authors showed that 8 -OHG levels increase in mRNA by $50 \%$ during dormancy alleviation. Job et al. (2005) observed massive protein oxidation processes during Arabidopsis thaliana seed germination. These authors found that mainly reserve proteins (12S subunits of cruciferin) are oxidized during seed maturation and that the same proteins gradually degrade during imbibition. Similar observations were made by Barba-Espín et al. (2011) through their research on pea seed germination. These authors also reported reserve protein carbonylation processes, i.e., vicilins and albumin 2 . The oxidation of seed storage proteins during seed 

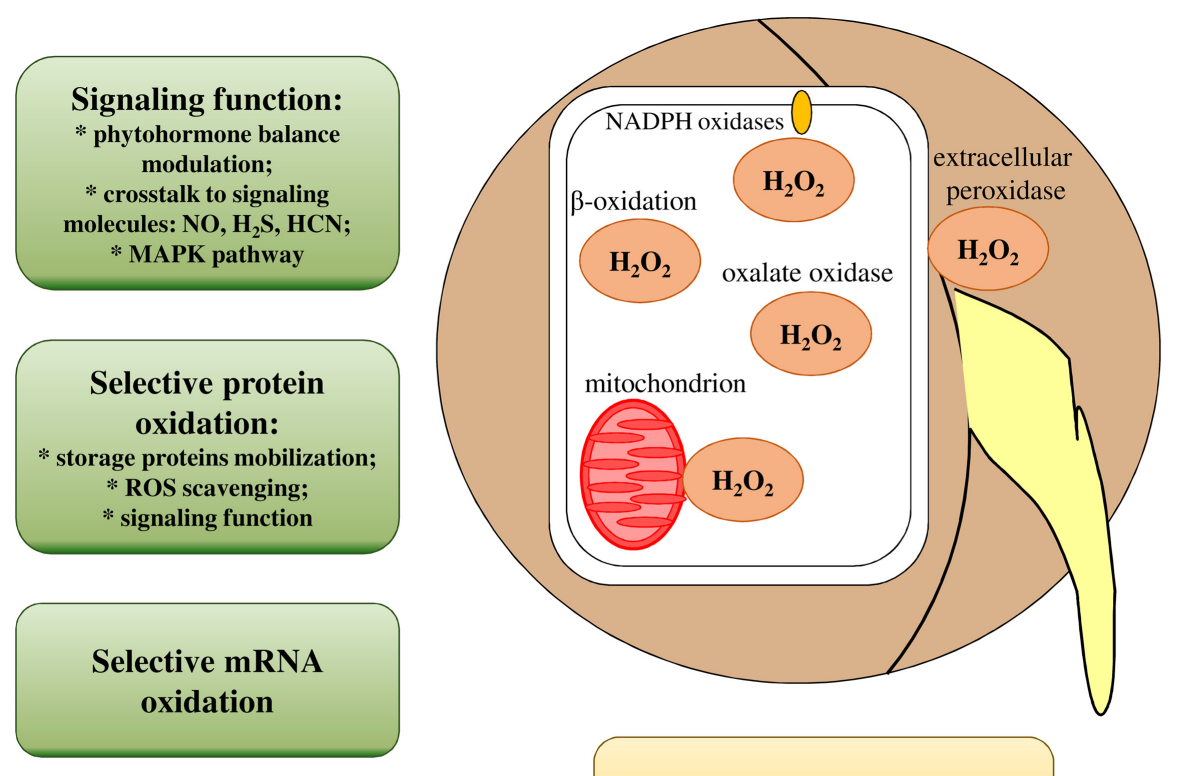

Regulation of $\mathrm{H}_{2} \mathrm{O}_{2}$ level by ROS scavenging mechanisms

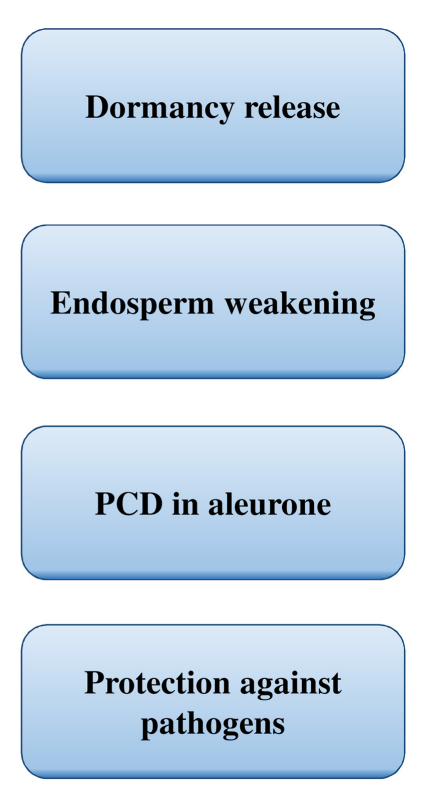

FIGURE 1 | Illustration of $\mathbf{H}_{2} \mathbf{O}_{2}$ functions during seed germination. Water uptake by seeds is fundamental for the reactivation of metabolism processes, for breaking dormancy and for seed germination. During imbibition, $\mathrm{H}_{2} \mathrm{O}_{2}$ production occurs through respiratory activities of mitochondria, through activities of $\beta$-oxidation pathways and through enzymes such as $\mathrm{NADPH}$ oxidases, extracellular peroxidases, and oxalate oxidases. $\mathrm{H}_{2} \mathrm{O}_{2}$ levels are also precisely controlled via antioxidative mechanisms. Signaling functions of $\mathrm{H}_{2} \mathrm{O}_{2}$ and crosstalk with other molecules and phytohormones and the selective oxidation of proteins and mRNA play key roles in germination regulation. $\mathrm{H}_{2} \mathrm{O}_{2}$ directly interrupts dormancy, weakens endosperm, induces PCD in aleurone cells and can present antimicrobial properties.

maturation can be essential to their future mobilization through proteolytic cleavage by the $20 \mathrm{~S}$ proteasome, which facilitates their mobilization during germination and seedling establishment through the destabilization of a highly compact seed storage protein complex (Job et al., 2005).

Verma et al. (2015) postulated that $\mathrm{H}_{2} \mathrm{O}_{2}$ and ROS production during germination contribute to reserve mobilization through oxidative modifications of stored proteins, which may be recognized by storage organs as signals to mobilize reserves to the rapidly growing axis. Due to the high abundance of seed storage proteins available, their oxidized forms can also be treated as scavenging systems for ROS (Job et al., 2005; Barba-Espín et al., 2011). The oxidation of proteins such as glycolytic enzymes, mitochondrial ATP synthase, aldolase reductase, methionine synthase, translation factors, and molecular chaperones (seemingly treated as deleterious effects) is a positive stimulator of germination, as specific oxidation processes can help protect other cell components against the negative effects of ROS. Moreover, the impairment of some metabolic activities (e.g., glycolytic enzymes) may lead to the activation of the pentose phosphate pathway (PPP), providing reducing power for antioxidant enzymes in the form of NADPH (Job et al., 2005; Barba-Espín et al., 2011). Oracz et al. (2007) proposed a mechanism for seed dormancy release that involves a change in proteome oxidation resulting from the accumulation of ROS during after-ripening phase. As the breaking of dormancy, both in dry and imbibed seeds, is accompanied by ROS production and by the carbonylation of specific embryo proteins, they assume a more general version of this mechanism. Based on these data, it can be concluded that ROS play an important role in seed proteome and transcriptome remodeling by selective oxidation, which can trigger dormancy release and germination (Diaz-Vivancos et al., 2013).

The germination of Arabidopsis, black peppercorns (Piper nigrum) and tomatoes (Lycopersicon esculentum) is limited by a mechanical barrier (e.g., endosperm). Germination can proceed when the mechanical barrier in the endosperm decreases. ROS can participate in endosperm weakening during germination through cell wall loosening. Müller et al. (2006, 2007) showed that $\mathrm{H}_{2} \mathrm{O}_{2}$ abolishes inhibitory effects of abscisic acid (ABA) on endosperm rupture. It has also been shown that during lettuce (Lactuca sativa) seed germination, exogenous ROS and ROS generation inducers increase the percentage of endosperm cap ruptures (Zhang et al., 2014b). Lariguet et al. (2013) suggested that $\mathrm{H}_{2} \mathrm{O}_{2}$ regulates the expression of gene encoding enzyme hydrolyzing the testa and endosperm, which facilitate Arabidopsis germination by releasing the embryo from the control of the seed envelope. However, seed dormancy and germination is not only controlled by the transcriptional regulation of gene expression. Rather, it is also controlled through the management of mRNA abundance and protein functioning (El-Maarouf-Bouteau et al., 2015). 
$\mathrm{H}_{2} \mathrm{O}_{2}$ likely regulates gene expression through protein oxidation, activation, and regulation of kinase transduction cascades, changes in the redox state of cysteine residues of transcription factors that regulate their activity and alteration in the cellular redox state, which is managed by ROS-antioxidant interactions (Job et al., 2005; Oracz et al., 2007; Barba-Espín et al., 2011; Bazin et al., 2011; Bykova et al., 2011a,b; El-MaaroufBouteau et al., 2013; Lariguet et al., 2013). Coordinate regulation at transcriptome and proteome levels during germination involves $\mathrm{H}_{2} \mathrm{O}_{2}$ - and ABA-mediated signaling through the mitogen-activated protein kinases (MAPK) pathway (BarbaEspín et al., 2011) and through the receptor for activated C kinase 1 (RACK1; Zhang et al., 2014a). RACK1 is a member of the tryptophan-aspartate repeat family of proteins, which performs multiple signaling functions in the growth and development of all eukaryotes (including plants; Zhang et al., 2014a).

During germination, $\mathrm{H}_{2} \mathrm{O}_{2}$ also protects against pathogens. $\mathrm{O}_{2}^{\bullet-}, \mathrm{H}_{2} \mathrm{O}_{2}$, and ${ }^{\bullet} \mathrm{OH}$ production in radish (Raphanus sativus) seeds has been shown to be a sign of the presence of active and developmentally controlled physiological processes that play a presumption role in protecting emerging seedlings from damages by pathogens (Schopfer et al., 2001). This hypothesis is based on the well-documented role of oxidative burst during pathogen infection, which leads to the induction of programmed cell death (PCD). However, ROS (mainly $\mathrm{H}_{2} \mathrm{O}_{2}$ ) also possess antimicrobial properties (Coll et al., 2011). Moreover, oxalate oxidase, which has previously been described as a germin, has been shown to catalyze the direct conversion of oxalate secreted by pathogenic fungi to $\mathrm{CO}_{2}$ and $\mathrm{H}_{2} \mathrm{O}_{2}$ during the germination of numerous species (Bolwell and Wojtaszek, 1997). Some evidence that reveals that the role of $\mathrm{H}_{2} \mathrm{O}_{2}$ in protecting against pathogens during germination and early seedling development is derived from studies on isolated lupine (Lupinus luteus) embryonic axes inoculated with Fusarium oxysporum, which causes the accumulation of $\mathrm{H}_{2} \mathrm{O}_{2}$ and free radicals (Morkunas et al., 2004). Biotic interactions between germinating seeds and microorganisms can also influence ROS levels through the stimulation of antioxidative capabilities, as is the case when tomato seeds are treated with the endophytic plant symbiont Trichoderma harzianum (Mastouri et al., 2010). The positive effects of $\mathrm{H}_{2} \mathrm{O}_{2}$ on germination have also been described for cereal grains in reference to their roles in PCD in aleurone (Fath et al., 2002). However, recent studies have shown that $\mathrm{H}_{2} \mathrm{O}_{2}$ may also be involved in mechanisms of ROS-dependent $\alpha$-amylase release in barley (Hordeum vulgare) aleurone cells (Ishibashi et al., 2012). A summary of processes that involve increased levels of $\mathrm{H}_{2} \mathrm{O}_{2}$ during germination is shown in Figure $\mathbf{1}$.

\section{$\mathrm{H}_{2} \mathrm{O}_{2}$ CROSSTALK WITH PHYTOHORMONES}

It is now widely accepted that $\mathrm{H}_{2} \mathrm{O}_{2}$ plays a dual function in living organisms during numerous metabolic processes under both neutral and stress conditions. $\mathrm{H}_{2} \mathrm{O}_{2}$ and other ROS can be generated as mechanisms that regulate plant growth, development, and responses to environmental stress through crosstalk with phytohormones. Recently published data support the existence of interactions between ROS and phytohormone signaling networks that modulate gene expression and cellular redox status (Xia et al., 2015b). Interrelationships and balance between phytohormones is of critical importance to the regulation of seed dormancy and germination (Figure 2) and has been reviewed and summarized in numerous studies (Brady and McCourt, 2003; Kucera et al., 2005; Finch-Savage and Leubner-Metzger, 2006; Daszkowska-Golec, 2011).

$\mathrm{H}_{2} \mathrm{O}_{2}$ interactions with phytohormones in the regulation of seed dormancy and germination are still a subject of discussion. Depending on the organs and biological processes involved, interactions between phytohormones and $\mathrm{H}_{2} \mathrm{O}_{2}$ can be either antagonistic or synergistic. ABA and gibberellic acid (GA) play opposite functions, and their roles in dormancy release and germination are essential and well established (Finch-Savage and Leubner-Metzger, 2006; Finkelstein et al., 2008; Nambara et al., 2010; Nonogaki et al., 2010; Weitbrecht et al., 2011; Graeber et al., 2012; Rajjou et al., 2012; Golldack et al., 2013), while the functions and interactions of other phytohormones during germination remain a subject of further research (Matilla and Matilla-Vázquez, 2008; Linkies et al., 2009; Linkies and Leubner-Metzger, 2012; Corbineau et al., 2014; Miransari and Smith, 2014). Pigeon pea (Cajanus cajan) seeds primed with auxin, cytokinin, GA, and ethylene (ET) exhibit improved germination results under both control and Cd-stress conditions (Sneideris et al., 2015). Similar effects have been observed during seed priming with ABA, but only at low concentrations. However, it is difficult to distinguish between positive effects of hydropriming and priming with phytohormones upon germination, as only high doses of ABA do not stimulate seed germination. This suggests that ABA inhibits germination at high concentrations, which has not been observed for auxin, cytokinin, GA, and ET (Sneideris et al., 2015).

The phytohormone cytokinin has been proposed to promote seed germination by antagonizing ABA suppression of seed germination. Interactions between $\mathrm{ABA}$ and cytokinin during seed germination and seedling growth mediated by interplays between transcriptional regulators have been found in Arabidopsis (Wang et al., 2011). The roles of interactions between cytokinin, ABA and GA in the regulation of heteromorphic plant dormancy and germination have been revealed through studies on Suaeda acuminata seeds (Wang et al., 2012b). Guan et al. (2014) identified a genetic pathway through which cytokinin specifically induces the degradation of ABI5 protein, thereby antagonizing the ABA-mediated inhibition of post-germinative growth in Arabidopsis. Functions of cytokinins in germination stimulation that involve counteracting inhibitory effects of ABA have been found in brown seed morphs of Suaeda acuminata (Wang et al., 2012b). Crosstalk between ABA and auxin has been found in numerous species, and auxin is known to affect germination in the presence of ABA, although the molecular mechanisms of such interactions remain unknown. Potential functions of ARF transcription factors and their regulation by miR160 in interactions between ABA and auxin during Arabidopsis seed germination and early growth were evidenced by Liu et al. (2007). Signaling processes trigger interactions 


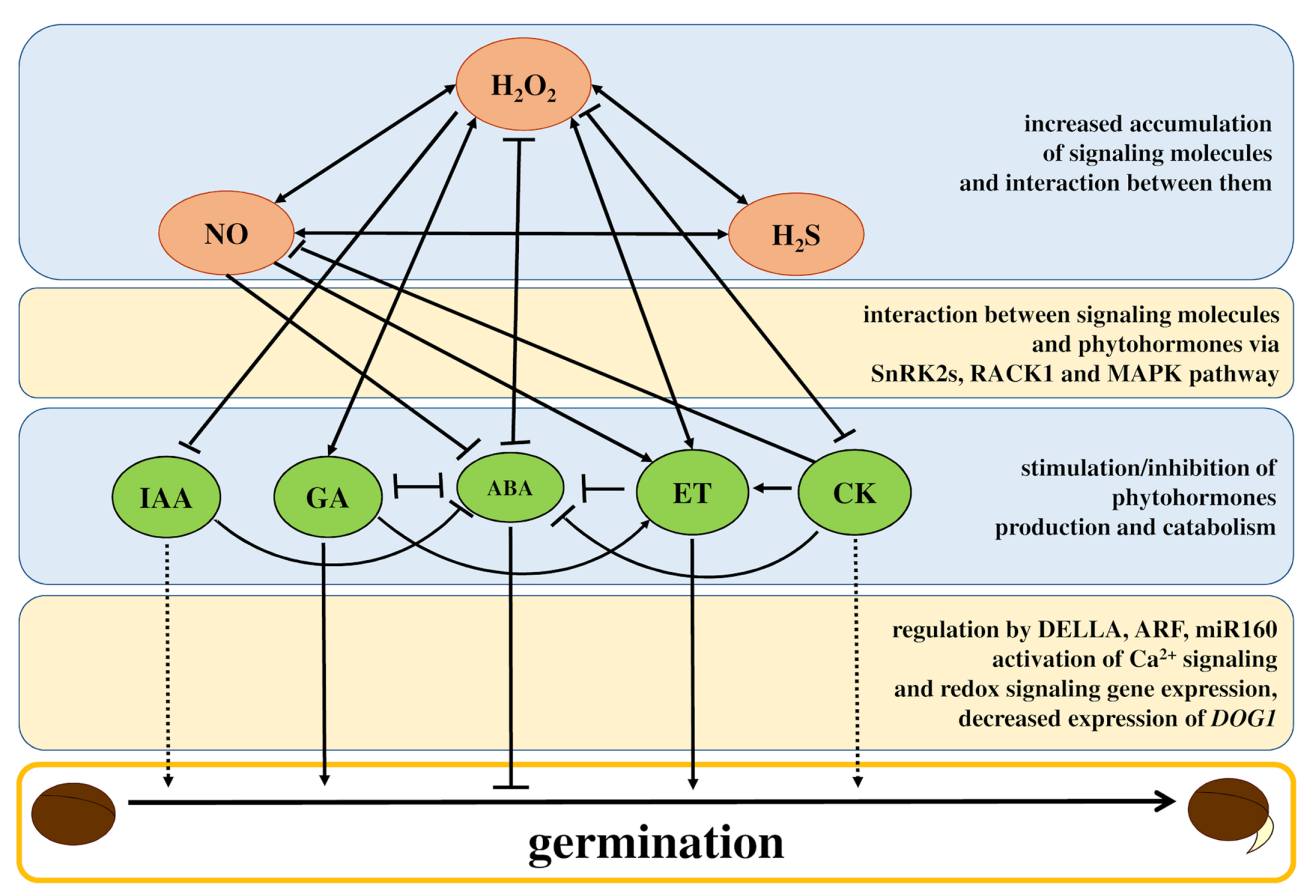

FIGURE 2 | Schema showing crosstalk between $\mathrm{H}_{2} \mathrm{O}_{2}$, NO, and $\mathrm{H}_{2} \mathrm{~S}$ and associated interactions with phytohormones for seed germination control. The accumulation of signaling molecules during imbibition influences phytohormone balance by decreasing abscisic acid (ABA), cytokinin (CK), and auxin (IAA) levels while increasing gibberellic acid (GA) and ethylene (ET). Combined effects of signaling molecules and phytohormones and signal transduction via SnRK2s, RACK1, and MAPK pathways lead to the control and regulation of transitions from the dormancy state to germination. Current concepts emphasize a primary role of GA and ET in promoting seed germination and germination inhibition by ABA while the function of IAA and CK in germination sensu stricto is debatable (marked by dashed line), however, both IAA and CK regulate cell division and cell growth in subsequent phases. The regulation of DELLA, ARF, miR160, and DOG gene expression and activity play key roles in this process. The phytohormonal regulation of dormancy breaking is accompanied by the activation of calcium signaling and redox signaling gene expression. Interactions and crosstalk between signaling molecules and phytohormones and their role in regulating germination are discussed in greater detail in the text. Positive or negative interactions are shown by arrows or bars, respectively.

not only between particular phytohormones but also between phytohormones and other signaling molecules such as NO (Arc et al., 2013b; Krasuska et al., 2015; Sanz et al., 2015), HCN (Oracz et al., 2008), $\mathrm{H}_{2} \mathrm{~S}$ (Jin and Pei, 2015), $\mathrm{OH}$ (Richards et al., 2015), and $\mathrm{H}_{2} \mathrm{O}_{2}$ (Diaz-Vivancos et al., 2013), which is believed to play a central role in signaling processes during plant development and stress responses (Petrov and Van Breusegem, 2012).

The seed germination of warm-season grasses is significantly responsive to oxidative conditions, and the complex interplay between seed redox status, $\mathrm{ABA}, \mathrm{H}_{2} \mathrm{O}_{2}$, and $\mathrm{NO}$ in this system has been highlighted (Sarath et al., 2007a,b). Studies on phytohormone interactions in germinated seeds have shown that exogenously applied ABA inhibits ROS accumulation in barley (Ishibashi et al., 2012), rice (Oryza sativa; Ye et al., 2012), lettuce (Zhang et al., 2014b), and sunflower (El-Maarouf-Bouteau et al., 2015). By contrast, the addition of GA enhances the production of ROS, and mainly through superoxide and $\mathrm{H}_{2} \mathrm{O}_{2}$ found in radish plants (Schopfer et al., 2001) and Arabidopsis (Liu et al., 2010; Lariguet et al., 2013). Bahin et al. (2011) suggested that $\mathrm{H}_{2} \mathrm{O}_{2}$ plays a role in the alleviation of barley seed dormancy through the activation of GA signaling and/or biosynthesis rather than through the inhibition of ABA signaling. They found that exogenously applied $\mathrm{H}_{2} \mathrm{O}_{2}$ does not influence ABA biosynthesis and signaling but that it has a more pronounced effect on GA signaling, resulting in the modulation of hormonal balance and in subsequent germination initiation. The modulation of phytohormone balance during germination by exogenously applied $\mathrm{H}_{2} \mathrm{O}_{2}$ is likewise a product of changes in $\mathrm{H}_{2} \mathrm{O}_{2}$ levels in seeds treated with GA and ABA. Enhanced superoxide and $\mathrm{H}_{2} \mathrm{O}_{2}$ production has been observed in Arabidopsis seeds treated with GA, and declines in ROS have been found in seeds treated with ABA (Lariguet et al., 2013).

Studies on $\mathrm{H}_{2} \mathrm{O}_{2}$ exogenously supplied under different light conditions have shown that $\mathrm{H}_{2} \mathrm{O}_{2}$ can either promote or repress germination depending on light qualities present (Lariguet et al., 2013). These authors concluded that the $\mathrm{H}_{2} \mathrm{O}_{2}$-dependent promotion of germination depends on phytochrome but not on cryptochrome signaling, which requires the presence of ROS interactions with GA. SnRK2 (plant-specific serine/threonine kinases) are involved in plant responses to abiotic stress and in ABA-dependent plant development (Kulik et al., 2011). Nakashima et al. (2009) stated that SnRK2 protein kinases are essential to the control of Arabidopsis seed development and dormancy. Ishibashi et al. (2012) speculated that the relationship between SnRK2 and ROS constitutes an essential factor in seed germination and dormancy and proposed a model describing the interactions of ROS in GA and ABA signaling in barley aleurone 
cells. Zhang et al. (2014a) concluded that OsRACK1A positively regulates rice seed germination by controlling endogenous levels of $\mathrm{ABA}$ and ROS and their interactions. In silico analysis suggests the presence of possible interactions between SnRK2 and RACK1, which may participate in signal transduction pathways that regulate seed dormancy and germination (Szklarczyk et al., 2015).

El-Maarouf-Bouteau et al. (2015) stated that ROS act together with $\mathrm{ABA}$ at the transcriptional level in sunflower plants mainly by decreasing the number of key targeted transcripts not through the stimulation of phytohormone-related gene expression required for germination (e.g., genes of GA or ET signaling pathways), but instead, through the set of genes related to calcium and redox signaling. They also suggest that the transcriptional regulation of sunflower seed germination is more closely related to the suppression of inhibitors than to the active transcription of stimulators. Barba-Espín et al. (2010) proposed an interaction between the redox state and phytohormones coordinated by $\mathrm{H}_{2} \mathrm{O}_{2}$ in the induction of proteins associated with plant signaling and development during pea seed germination. They observed better germination performance accompanied by decreases in ABA, zeatin-riboside, salicylic acid, jasmonic acid, and indole acetic acid levels in germinated peas with exogenously supplied $\mathrm{H}_{2} \mathrm{O}_{2}$, supporting their conclusion that $\mathrm{H}_{2} \mathrm{O}_{2}$ can directly act as a messenger within the phytohormonal network and as a signaling molecule involved in the germination of orthodox seeds. The central and integrative role of $\mathrm{H}_{2} \mathrm{O}_{2}$ in the regulation of sunflower seed germination via phytohormones such as ET, ABA, GA, jasmonic acid, and salicylic acid was also postulated by El-Maarouf-Bouteau et al. (2015).

The function of $\mathrm{H}_{2} \mathrm{O}_{2}$ as a management center that balances phytohormone interactions for germination purposes could occur via MAPK (Barba-Espín et al., 2011). Two mechanisms for $\mathrm{H}_{2} \mathrm{O}_{2}$-driven MAPK signaling in germinating pea seeds have been proposed. According to the first model, exogenously added $\mathrm{H}_{2} \mathrm{O}_{2}$ induces a MAPK-dependent decrease in ABA content in seeds. The second model assumes direct or indirect negative effects of $\mathrm{H}_{2} \mathrm{O}_{2}$ on $\mathrm{ABA}$ transport from the cotyledon to the embryonic axis, resulting in a decrease in ABA. Finally, decreases in ABA may induce a MAPK-mediated reduction in the ET precursor (ACC, 1-aminocyclopropane carboxylic acid), favoring germination (Barba-Espín et al., 2011, 2012). One study on the interactive roles of GA, ABA and ET and on the possible involvement of ROS in the mediation of phytohormone actions during mung bean (Vigna radiata) seed germination shows that ET essentially has a positive effect on seed germination with possible interactions with ROS (Chaudhuri et al., 2013).

Ethylene may mainly promote radial cell expansion in the embryonic hypocotyl, increase seed respiration, decrease seed base water potential, or enhance the expression of cell wall hydrolases in the endosperm cap (Chaudhuri et al., 2013). Linkies et al. (2009) showed that the inhibitory effects of ABA on Lepidium sativum seed germination are counteracted by ET and proposed a model on the phytohormonal regulation of endosperm cap weakening and rupture. Observations on germinating lettuce seeds show that when seeds are imbibed in water, the $\mathrm{H}_{2} \mathrm{O}_{2}$ content in the cap increases prior to cap rupture and decreases thereafter, whereas $\mathrm{H}_{2} \mathrm{O}_{2}$ content in the radicle remains very low (Zhang et al., 2014b). El-Maarouf-Bouteau et al. (2015) proposed that ET production at the end of the pea seed germination process correlates with ROS accumulation and that ROS and ET together participate in the initiation of cell elongation (the first visible symptom of germination completion), which has also been suggested for apples (Malus domestica; Gniazdowska et al., 2010a,b) and soybeans (Glycine max; Ishibashi et al., 2013) and in reference to the initiation of cell division.

Corbineau et al. (2014) proposed that ET plays a central role in seed dormancy regulation via crosstalk between phytohormones and other signals, although information on the interrelationship between ET and $\mathrm{H}_{2} \mathrm{O}_{2}$ in the regulation of seed germination remains limited and inconsistent. Various mechanisms that fine-tune ROS production and accumulation operate during seed germination (and include the action of phytohormones). Antioxidant functions of cytokinin in healthy soybean seeds have been postulated by Gidrol et al. (1994). The accumulation of ROS during germination leads to the oxidation of endogenous cytokinin (Gidrol et al., 1994), which abolishes their functions. Cytokinins also interact with NO, thus demonstrating that antagonistic effects on seed germination and can act as suppressors of NO, as shown for Arabidopsis (Liu et al., 2013).

\section{$\mathrm{H}_{2} \mathrm{O}_{2}$ CROSSTALK WITH SIGNALING MOLECULES}

While the role of $\mathrm{H}_{2} \mathrm{O}_{2}$ and $\mathrm{NO}$ in seed biology has been studied widely, knowledge regarding the functions of other molecules and on their interactions remains scarce. Both NO and $\mathrm{H}_{2} \mathrm{O}_{2}$ perform a parallel function in terms of interrupting germination dormancy and stimulation through interactions with ABA (Figure 2). In reference to seed physiology, the model on crosstalk between ROS, NO, and ABA differs from the well-established model on stomatal guard cell regulation (Arc et al., 2013a,b). Seed imbibition increases $\mathrm{H}_{2} \mathrm{O}_{2}$ and $\mathrm{NO}$ levels. $\mathrm{H}_{2} \mathrm{O}_{2}$ up-regulates $\mathrm{ABA}$ catabolism (most likely through an NO signal) while also promoting GA biosynthesis (Liu et al., 2010; Arc et al., 2013b). Similar to $\mathrm{H}_{2} \mathrm{O}_{2}$, the exogenous application of NO imposes seed dormancy and diminishes the inhibitory effects of ABA on seed germination (Bethke et al., 2004, 2006). The application of NO also stimulates seed germination under stress conditions (Kopyra and Gwóźdź, 2003; Zheng et al., 2009).

Liu et al. (2010) proposed a hypothetical model that explains interrelationships between $\mathrm{H}_{2} \mathrm{O}_{2}$ and $\mathrm{NO}$ in the regulation of seed germination by joint actions of $\mathrm{ABA}$ and GA. According to this model, $\mathrm{H}_{2} \mathrm{O}_{2}$ can interrupt the dormancy of Arabidopsis seeds through two pathways. The first pathway relies on the enhancement of ABA catabolism and GA biosynthesis. The signaling molecule $(\mathrm{NO})$ does not regulate GA biosynthesis directly but instead acts as a temporary signaling molecule involved in the $\mathrm{H}_{2} \mathrm{O}_{2}$ regulation of $\mathrm{ABA}$ catabolism. The second 
pathway assumes the negative regulation of GA biosynthesis by ABA. Bahin et al. (2011) suggested that $\mathrm{H}_{2} \mathrm{O}_{2}$ interrupts dormancy in barley seeds through GA signaling activation rather than influencing ABA metabolism. Gniazdowska et al. (2010c) proposed a function for $\mathrm{H}_{2} \mathrm{O}_{2}$ in apple seed germination and its role in the downstream signaling of $\mathrm{NO}$ and $\mathrm{HCN}$ in the activation of ET biosynthesis during early seedling growth. They also found that the activities of crucial enzymes involved in ET metabolism are modified by HCN and NO treatments.

Oracz et al. (2009) presented a comprehensive scheme on the mechanism of HCN-dependent dormancy alleviation and on its crosstalk to ROS as a decisive signaling element involved in seed germination. The dominant role of ROS and reactive nitrogen species (RNS) in the regulation of seed dormancy and germination is also discussed. The authors postulate that NO may play a key role in germination vigor, which may result from crosstalk between NO and ROS (Arc et al., 2013a). Krasuska and Gniazdowska (2012) stated that ROS, $\mathrm{NO}$, and HCN can simultaneously affect embryo dormancy release processes and that their accurate levels are essential to seed germination and development regulation. Based on the "oxidative window" model, a model proposed by Bailly et al. (2008) that describes regulating functions of ROS in seed dormancy/germination switch, Krasuska and Gniazdowska (2012) presented the "nitrosative door" hypothesis, which focuses on the concentration-dependent role of RNS (mainly in terms of NO in seed physiology). They also proposed that RNS and ROS levels are strictly regulated by ROS scavenging enzymes.

Wang et al. (2015b) presented a mechanism of NO suppression on the inhibitory effects of ABA on seed germination. Based on studies related to interactions between $\mathrm{ABA}, \mathrm{NO}$, and ROS in stomatal guard cells and based on their own results, Wang et al. (2015b) suggested that NO negatively regulates ABA signaling through $S$-nitrosylation of SnRK2s proteins (SnRK2.2, SnRK2.3, and SnRK2.6/OST1) not only in terms of stomatal closure but also in terms of the inhibition of seed germination and seedling growth. They proposed that $S$-nitrosylation of SnRK2s proteins serves as a key component of signaling crosstalk between ABA and NO that regulates Arabidopsis seed germination. They described a mechanism for $\mathrm{NO}$ involvement in dormancy release and germination promotion. Based on their findings, endogenous and exogenously applied NO exerts inhibitory effects on the kinase activities of SnRK2.2 and SnRK2.3 via S-nitrosylation and thus blocks ABA signaling (Wang et al., 2015b).

Interest in the $\mathrm{H}_{2} \mathrm{~S}$ molecule has grown in plant biology research. This is due to its signaling functions and interactions with $\mathrm{H}_{2} \mathrm{O}_{2}$ and $\mathrm{NO}$ during plant development and stress responses (Calderwood and Kopriva, 2014; Hancock and Whiteman, 2014, 2015; Jin and Pei, 2015) and during seed germination (Li, 2013). Improved germination and decreases in germination time periods have been observed in common bean (Phaseolus vulgaris), maize (Zea mays), wheat (Triticum aestivum), and pea seeds subjected to $\mathrm{H}_{2} \mathrm{~S}$ treatments (Dooley et al., 2013). These results suggest that $\mathrm{H}_{2} \mathrm{~S}$ plays an important role as a signaling molecule that can accelerate growth rates of numerous plant species. Positive effects of $\mathrm{H}_{2} \mathrm{~S}$ and $\mathrm{H}_{2} \mathrm{O}_{2}$ treatments on the promotion of mung bean seed germination have been observed by $\mathrm{Li}$ and $\mathrm{He}$ (2015). These authors suggest that $\mathrm{H}_{2} \mathrm{O}_{2}$ and $\mathrm{H}_{2} \mathrm{~S}$ may promote the germination of mung bean seeds by mobilizing reserve proteins and that $\mathrm{H}_{2} \mathrm{O}_{2}$ may serve as a downstream signaling molecule of $\mathrm{H}_{2} \mathrm{~S}$.

Li et al. (2012) proposed the existence of crosstalk between $\mathrm{H}_{2} \mathrm{O}_{2}$ and $\mathrm{H}_{2} \mathrm{~S}$ during seed germination. The authors found improved germination percentages for Jatropha curcas seeds soaked in $\mathrm{H}_{2} \mathrm{O}_{2}$ accompanied by an increase in L-cysteine desulfhydrase activity that induce $\mathrm{H}_{2} \mathrm{~S}$ accumulation. Moreover, Li et al. (2012) observed better germination performance after adding $\mathrm{H}_{2} \mathrm{~S}$ to a soaking solution and postulated that this improvement is mediated by $\mathrm{H}_{2} \mathrm{~S}$. In the signaling process mediated by $\mathrm{H}_{2} \mathrm{~S}$ during seed germination, both $\mathrm{H}_{2} \mathrm{O}_{2}$ and $\mathrm{NO}$ play important roles. In $\mathrm{NaCl}$-stressed alfalfa (Medicago sativa) seeds, both $\mathrm{H}_{2} \mathrm{~S}$ (sodium hydrosulfide) and NO donors (sodium nitroprusside) can significantly attenuate seed germination and seedling growth inhibition by protecting against oxidative damage (Wang et al., 2012a). The authors also showed that the application of $\mathrm{H}_{2} \mathrm{~S}$ donor enhances $\mathrm{NO}$ accumulation while the addition of 2-phenyl-4,4,5,5-tetramethylimidazoline-1-oxyl 3-oxide (PTIO), a specific NO scavenger, diminishes positive impacts of $\mathrm{H}_{2} \mathrm{~S}$ on germination and $\mathrm{NaCl}$ stress tolerance, suggesting the presence of interactions between $\mathrm{H}_{2} \mathrm{~S}$ and $\mathrm{NO}$ in germinating seeds. A schematic illustration of interrelationships and crosstalk between signaling molecules and phytohormones during the regulation of seed germination is presented in Figure 2.

\section{$\mathrm{H}_{2} \mathrm{O}_{2}$ PRIMING-INDUCED ABIOTIC STRESS TOLERANCE}

Seed vigor is an important agronomic trait that determines a seed's potential for rapid uniform emergence and development under a broad range of field conditions (Catusse et al., 2008; Rajjou et al., 2012; Ventura et al., 2012). Modern approaches to seed quality improvement involve classical genetics, molecular biology and invigoration treatments known as priming treatments. Seed priming is a pre-sowing treatment that is widely used in the vegetable and flower seed industry to enhance seedling establishment, crop stands and yields (Bradford, 1986; Di Girolamo and Barbanti, 2012; Bewley et al., 2013; Jisha et al., 2013; Paparella et al., 2015). This technique involves imbibing seeds with restricted amounts of water to create hydration conditions that permit pre-germinative metabolic events to proceed while preventing radicle protrusion.

In most plant species, seeds remain desiccation-tolerant prior to radicle emergence (Hilhorst et al., 2010), and thus seeds can be dried to their original moisture levels after being soaked for storage, distribution and sowing via conventional techniques. However, primed seed storage is a major challenge involved in seed priming (Argerich et al., 1989; Hussain et al., 2015). Priming treatments have beneficial effects on seed vigor and viability, which manifest as improved germination performance (increased germination rates, total germination percentages, and germination uniformity) and plant growth, 
especially under adverse environmental conditions (Figure 3), (Ashraf and Foolad, 2005; Chen and Arora, 2011; Yacoubi et al., 2011; Chen et al., 2012; Jisha and Puthur, 2015; Kubala et al., 2015a,b; Salah et al., 2015). Depending on the plant species, seed morphology and physiology, a variety of physicochemical and biological priming treatments can be applied. Currently available priming techniques include hydropriming (soaking seeds in predetermined amounts of water or limiting imbibition periods), osmopriming [soaking seeds in osmotic solutions (e.g., PEG) or in salt solutions], matrix priming (mixing seeds with organic or inorganic solid materials and water in known proportions and in some cases adding chemical or biological agents), chemical priming (soaking seeds in various chemical solutions), hormonal priming (treating seeds with plant growth regulators) and biological priming/biopriming (using beneficial microorganisms to seed during priming; Di Girolamo and Barbanti, 2012; Jisha et al., 2013; Paparella et al., 2015).

Priming enhanced germination performance may be considered a result of advanced germination metabolism processes (Soeda et al., 2005) involving more efficient respiratory pathways (Li et al., 2010; Sun et al., 2011), enhanced antioxidant activity (Bailly et al., 1998, 2000; Posmyk et al., 2001; Chen and Arora, 2011; Yacoubi et al., 2011), initiated repairing processes (Balestrazzi et al., 2011; Kibinza et al., 2011), and altered phytohormonal balance (El-Araby et al., 2006). Higher expressions of genes and proteins involved in water transport, cell wall modification, cytoskeletal organization, and cell division and increases in protein synthesis potential, post-translational processing capacity, and targeted proteolysis have been linked to the advanced germination of primed seeds (Gao et al., 1999; Gallardo et al., 2001; Chen and Arora, 2013; Kubala et al., 2015a). However, priming involves other specific mechanisms that improve germination and thus priming cannot simply be viewed as an acceleration of germination-related processes.

Priming procedures can generate moderate levels of abiotic stress during both soaking (e.g., osmotic stress, salinity, and drought generated by priming agents) and dehydration phases (Ashraf and Foolad, 2005; Kubala et al., 2015a). This abiotic stress generated during priming can activate stress-responsive systems in primed seeds that lead to enhanced tolerance levels to subsequent stress during post-priming germination and seedling establishment (Chen and Arora, 2013). Beneficial effects of seed priming are also observed during more advanced developmental stages (Bruce et al., 2007; Patade et al., 2011) and throughout the entire growing season (Iqbal and Ashraf, 2006, 2007; Hussain et al., 2014). It will be worthwhile to determine whether seed priming effects can be perpetuated to the next generation as in the case of priming-induced transgenerational resistance that protects future generations against biotic stress (Luna and Ton, 2012; Slaughter et al., 2012).

Seed priming improves the stress tolerance of germinating seeds and plants grown from primed seeds based facilitating faster transitions to the germinated state and the activation of stress-responsive systems. These two strategies constitute "priming memory" or stress imprinting mechanisms, which cover genetic or biochemical modifications induced by priming, which in turn can occur as a result of subsequent stress exposure and which mediate enhanced tolerance of subsequent stress (Chen and Arora, 2013). Kubala et al. (2015b) showed that after initial stress exposure, primed rape (Brassica napus) seeds present salinity stress tolerance during post-priming germination, a feature that is likely linked to "priming memory."

In addition to water-based priming with controlled seed imbibition, priming treatments on vegetative plant parts are often used. Initial plant exposure to stressors or chemical compounds results in the faster and stronger induction of basal resistance mechanisms upon the onset of subsequent pathogen attacks or in greater tolerance against abiotic stresses, as reviewed by Tanou et al. (2012), Pastor et al. (2013), and Hossain et al. (2015). Numerous priming-inducing chemicals are endogenous plant compounds (e.g., $\mathrm{H}_{2} \mathrm{O}_{2}$ ). Beneficial effects of exogenous $\mathrm{H}_{2} \mathrm{O}_{2}$ applied in the form of foliar spray on the induction of tolerance to drought, salinity, chilling, high temperatures, and heavy metal stress, all of which modulate $\mathrm{H}_{2} \mathrm{O}_{2}$ production, were recently summarized by Hossain et al. (2015). These authors proposed a hypothetical model on the effects of $\mathrm{H}_{2} \mathrm{O}_{2}$ on plant defense mechanisms associated with abiotic stress. It is speculated that $\mathrm{H}_{2} \mathrm{O}_{2}$ treatments that involve seed soaking or the use of foliar spray induce low levels of oxidative stress and that ROS (especially $\mathrm{H}_{2} \mathrm{O}_{2}$-dependent signaling networks) induce the accumulation of latent defense proteins, resulting in the generation of primed states and in improved stress responses (Hossain et al., 2015). Positive effects of seed priming with $\mathrm{H}_{2} \mathrm{O}_{2}$ in terms of enhancing salt and high temperature tolerance in barley, drought tolerance in wheat and common bean and soil moisture stress tolerance in cotton (Gossypium hirsutum) have been shown (He et al., 2009; Cavusoglu and Kabar, 2010; Abass and Mohamed, 2011; Santhy et al., 2014). Priming with $\mathrm{H}_{2} \mathrm{O}_{2}$ also improves spring maize seedling growth under suboptimal temperatures (Ahmad et al., 2015).

The above findings show that the stress tolerance of germinating seeds and seedlings brought about through seed pretreatment with $\mathrm{H}_{2} \mathrm{O}_{2}$ is attributable to the reduction of endogenous $\mathrm{H}_{2} \mathrm{O}_{2}$ content, to more effective antioxidative systems, to the expression of stress proteins, to improved membrane stability and to high photosynthetic capacity, which help alleviate damage while stimulating growth under stress (Figure 3). Enhanced levels of endogenous $\mathrm{H}_{2} \mathrm{O}_{2}$ accompanied by proline accumulation have been observed during the osmopriming and post-priming germination of rape seeds (Kubala et al., 2015b). The authors have stated that higher levels of $\mathrm{H}_{2} \mathrm{O}_{2}$ accumulation in primed seeds associated with higher proline content, gene expression, and enzymatic activity of pyrroline-5-carboxylate synthetase (P5CS) suggest that $\mathrm{H}_{2} \mathrm{O}_{2}$ and proline play a crucial role in improving salinity tolerance by osmopriming. However, tomato priming with various priming solutions (kinetin, $\mathrm{KNO}_{3}, \mathrm{NaCl}, \mathrm{KH}_{2} \mathrm{PO}_{4}$, and $\mathrm{CaCl}_{2} \cdot 2 \mathrm{H}_{2} \mathrm{O}$ ) were decreases the $\mathrm{H}_{2} \mathrm{O}_{2}$ production under $\mathrm{NaCl}$ stress (Theerakulpisut et al., 2011).

The treatment of seeds with exogenous $\mathrm{H}_{2} \mathrm{O}_{2}$ and subsequent germination without drying to initial moisture content (MC) improves the salt tolerance of wheat seedlings by alleviating oxidative damage, enhancing stress protein expression (Wahid et al., 2007), aluminum-induced oxidative stress mitigation in 


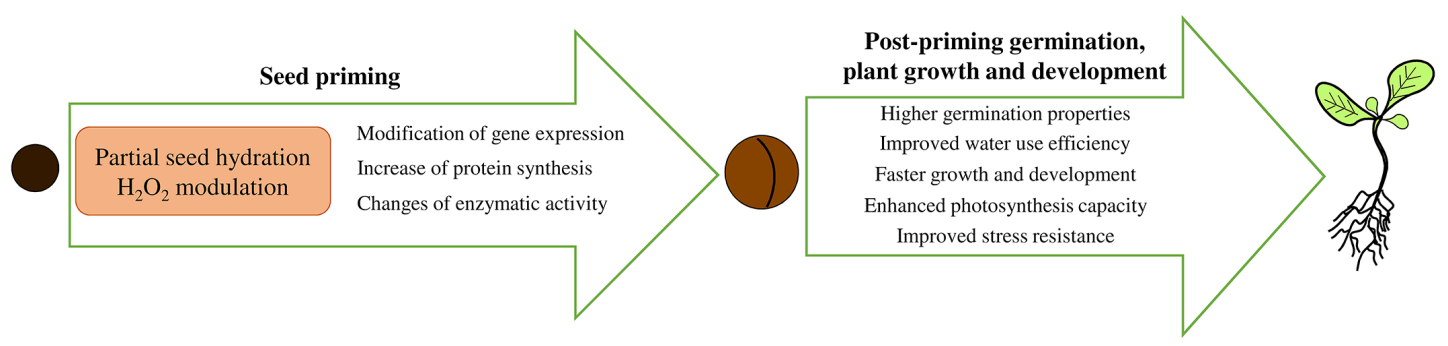

FIGURE 3 | Schema on the central role of priming-induced hydrogen peroxide modulation in improving post-priming germination, seedling growth, and stress tolerance. Partial seed hydration during pre-sowing priming and $\mathrm{H}_{2} \mathrm{O}_{2}$ metabolism modulation control cellular processes through gene expression regulation, increased protein synthesis, and changes in enzymatic activity.

wheat seedlings ( $\mathrm{Xu}$ et al., 2011a) and antioxidant system and nutrient relation modulation in maize plants under waterdeficit conditions (Ashraf et al., 2015). Seed treatment with $\mathrm{H}_{2} \mathrm{O}_{2}$ also enhances the germination and seedling growth of sunflower plants and modifies net photosynthetic rates and antioxidant systems in mung bean plants under non-stressed conditions (Wahid et al., 2008; Khan et al., 2015). Comparisons between the effectiveness of the surface drying and re-drying of soaked seeds show no difference between these two strategies in regards to post-priming germination and seedling growth (Farooq et al., 2010). In taking these results into account, it can be concluded that the pretreatment of seeds with $\mathrm{H}_{2} \mathrm{O}_{2}$ may have similar effects on germination performance, seedling growth, and metabolic processes as priming treatments, although it seems that dehydration after seed soaking plays an important role in the regulation of gene expression and protein accumulation (Kubala et al., 2015a).

Regardless of the seed invigoration method applied, enhanced abiotic stress tolerance was achieved through $\mathrm{H}_{2} \mathrm{O}_{2}$ level modulation and regulation of multiple stress-responsive pathways. The capacity to alleviate the production of ROS serves as an important component of stress tolerance in both seeds and plants (Kranner and Seal, 2013). Seed heteromorphism, i.e., the production of different seed morphs with different germination characteristics by a single individual, has been found in a number of halophytic taxa as a means of responding to harsh environments (Li et al., 2005; Cao et al., 2015). Studies on seedlings derived from dimorphic seeds of Atriplex centralasiatica reveal differential salt tolerance levels as a result of different levels of $\mathrm{H}_{2} \mathrm{O}_{2}$ caused by the modulation of antioxidative enzyme activities by $\mathrm{NO}$ (Xu et al., 2011b).

It is well established that primed seeds are developmentally more advanced to reach complete germination than unprimed ones (Chen and Arora, 2013). Similarly, treating seeds with activators of plant defense against pathogen and herbivores is not accompanied by a reduction in growth (Worrall et al., 2012). Plant priming for the enhanced induction of defense responses is often accompanied by compromised plant performance (Chinnusamy and Zhu, 2009) but requires lower fitness costs than the direct induction of defenses (Van Hulten et al., 2006). Seed priming is economically more attractive than chemical plant treatments applied to plants in field conditions. Therefore, a further examination of molecular mechanisms that support seed priming is not only of fundamental importance but also of practical importance, as such studies may help us to uncover fruitful agricultural strategies.

\section{ROLES OF $\mathrm{H}_{2} \mathrm{O}_{2}$ IN SEED AGING}

Seed aging involves the gradual accumulation of damage to cellular components, which in turn results in a loss of seed viability and vigor. This process occurs during prolonged seed storage and escalates when seeds are stored in improper conditions (especially in high temperature and moisture conditions; Arc et al., 2011). As stored seeds lose longevity over time, it is critically important to understand the mechanisms of the aging process that are related to agronomic and ecological (ex situ seed conservation) factors. It is worth emphasizing that rates of aging and seed longevity vary between species. The lifespan of stored seeds depends not only on storage periods and conditions but also on genetic, physiological, and morphological factors (seed structures, compositions of reserves, seed maturation programs, etc.; Walters et al., 2005; Ventura et al., 2012). Deleterious effects of seed aging are commonly examined using artificial aging methods (controlled deterioration test, CDT and accelerated aging, AA) that involve seed exposition to high temperature $\left(\geq 35^{\circ} \mathrm{C}\right)$ and humidity $(\geq 75 \% \mathrm{RH})$ conditions for relatively short periods of time (Black et al., 2006). These techniques are designed to hasten and mimic the natural aging process (the prolonged storage of dry seeds). However, doubts have been raised regarding whether CDT and AA treatments accurately convey mechanisms of seed deterioration as a result of natural aging processes (Murthy et al., 2003; Lehner et al., 2008; Schwember and Bradford, 2010; Groot et al., 2012). Differences may result mainly from the partial hydration of seeds during CDT and AA, which can activate biochemical pathways not found in dry seeds (Bewley et al., 2013).

Although the biochemical and molecular basis of the seed aging process is still not fully understood, it is well established that seed aging causes several deleterious changes within cells (e.g., DNA damage, a loss of RNA synthesis reflecting impaired protein production, a loss of membrane integrity, mitochondrial dysfunction, protein inactivation, telomere shortening, etc.; 
McDonald, 1999; Fu et al., 2015). According to the "free radical theory of aging," the driving force behind most alterations that occur during the aging of living organisms is ROS activity. This assumption also refers to aged seeds and is supported by numerous reports (Rajjou et al., 2008; Bellani et al., 2012; Hu et al., 2012; Parkhey et al., 2012; Yao et al., 2012; Xin et al., 2014; Ratajczak et al., 2015). ROS production in dry stored seeds ensues as a result of non-enzymatic processes (e.g., Amadori and Maillard reactions and lipid peroxidation; El-Maarouf-Bouteau and Bailly, 2008).

Oxidative damage in dry seeds may also be propagated as a result of inefficient enzymatic antioxidant machinery operating under low water content conditions. When seeds are hydrated to a certain extent (e.g., during artificial aging or seed storage in uncontrolled environments), ROS synthesis also occurs as a result of enzymatic reactions and respiratory activities (Bewley et al., 2013). $\mathrm{H}_{2} \mathrm{O}_{2}$, as a long-lived ROS, is able to migrate across membranes over relatively long distances and thus contribute to the aging process (Kibinza et al., 2006, 2011; Lehner et al., 2008; Xin et al., 2014; Kalemba et al., 2015; Kong et al., 2015; Ratajczak et al., 2015). Negative interrelationships between the viability/germination capacities of seeds and $\mathrm{H}_{2} \mathrm{O}_{2}$ accumulation during aging have been shown for artificially aged sunflower (Bailly et al., 1996; Kibinza et al., 2006, 2011), beech (Fagus sylvatica; Pukacka and Ratajczak, 2005, 2007), and wheat seeds (Lehner et al., 2008) and for naturally aged cotton (Gossypium hirsutum; Goel and Sheoran, 2003) and beech seeds (Ratajczak et al., 2015).

Kibinza et al. (2006) found that $\mathrm{H}_{2} \mathrm{O}_{2}$ levels in the embryonic axis depend on seed moisture levels and increase in a sublinear manner with increasing water content. Positive relationships have also been found between $\mathrm{H}_{2} \mathrm{O}_{2}$ production and energy metabolism, indicating that respiratory electron transport enhancement as a result of higher water status leads to the overproduction of $\mathrm{H}_{2} \mathrm{O}_{2}$, which in turn induces ATP depletion in aged seeds. Thus, MC seems to play a major role in seed deterioration (Kibinza et al., 2006). An analogous trend in terms of $\mathrm{H}_{2} \mathrm{O}_{2}$ level changes as a function of $\mathrm{MC}$ was obtained for artificially aged oat (Avena sativa), wheat, and beech seeds (Pukacka and Ratajczak, 2005; Lehner et al., 2008; Kong et al., 2015). However, in aged oat seeds, $\mathrm{H}_{2} \mathrm{O}_{2}$ accumulation is only associated with $\mathrm{MC}$ over long storage periods (Kong et al., 2015). An increasing amount of $\mathrm{H}_{2} \mathrm{O}_{2}$ and of other reactive oxygen species during seed deterioration is also a reflection of the progressive depletion of enzymatic scavenger activities. Alterations of activity and of transcript levels of key antioxidant enzymes have been observed in aged seeds of different species (Bailly et al., 1996; Goel et al., 2003; Kibinza et al., 2006, 2011; Pukacka and Ratajczak, 2007; Lehner et al., 2008; Yao et al., 2012; Chen et al., 2013; Morscher et al., 2015; Ratajczak et al., 2015; Xia et al., 2015a).

A study on oat seeds showed that enzymatic antioxidants such as CAT, APX, and SOD can protect against oxidative stress in stored seeds with low MC, whereas when high levels of MC are present, these enzymes are heavily limited, and proline seems to play a more prominent role in the response to oxidative stress (Kong et al., 2015). The effects of $\mathrm{O}_{2}{ }^{\bullet-}$ and $\mathrm{H}_{2} \mathrm{O}_{2}$ on seed viability during storage under different temperatures were examined in black poplar (Populus nigra). The authors showed that after 2 years of storage, $\mathrm{H}_{2} \mathrm{O}_{2}$ accumulation is responsible for alterations of membrane permeability as a result of the changing compositions of fatty acids and phospholipids (Kalemba et al., 2015).

In naturally aged beech seeds, the production of $\mathrm{H}_{2} \mathrm{O}_{2}$ and of other $\operatorname{ROS}\left(\mathrm{O}_{2}{ }^{\bullet-},{ }^{\bullet} \mathrm{OH}\right)$ is significantly higher in the embryonic axis than in cotyledons, suggesting that embryonic axes are more sensitive to storage and damage (e.g., DNA fragmentation). Nevertheless, whether found in the embryonic axis or in cotyledons, ROS accumulation is dependent on seed storage periods and it is accompanied by a loss of membrane integrity. Based on results obtained via the in situ localization of $\mathrm{H}_{2} \mathrm{O}_{2}$, $\mathrm{O}_{2}{ }^{\bullet-}$, and ${ }^{\bullet} \mathrm{OH}$, the authors suggest that losses in germination ability may also be a result of ROS-derived deleterious effects on cell division processes in root apical meristems of stored seeds, thus leading to the prevention of radicle protrusion (Ratajczak et al., 2015). However, some published data call the main role of $\mathrm{H}_{2} \mathrm{O}_{2}$ and of other reactive species in the aging process into question (Cakmak et al., 2010; Yin et al., 2015). In naturally aged alfalfa seeds, lipid peroxidation is the main product of long-term storage, although there is no correlation with $\mathrm{H}_{2} \mathrm{O}_{2}$, as the latter remains at a low level in aged dry seeds (Cakmak et al., 2010).

More recently, Yin et al. (2015) found that artificial aging treatments delay rape seed germination and increase ion leakage but do not promote $\mathrm{H}_{2} \mathrm{O}_{2}$ generation or the accumulation of any antioxidant enzymes (apart from peroxiredoxin). However, CDT treatments were found to affect SOD and CAT activates. The authors suggest that in Brassica napus, the over-accumulation of ROS does not act as a primary factor in initiating seed deterioration and other mechanisms (e.g., germination inhibitor synthesis and ABA content enhancement) are involved in the aging process (Yin et al., 2015). Some data indicate that losses in seed viability during aging are related to PCD (Kranner et al., 2011; Chen et al., 2013). As $\mathrm{H}_{2} \mathrm{O}_{2}$ and other ROS are considered to act as main modulators that control PCD in plant tissues (Gadjev et al., 2008), these molecules are likely also involved in signal transduction mediation that leads to PCD in aged seeds. Kibinza et al. (2006) speculated that $\mathrm{H}_{2} \mathrm{O}_{2}$-dependent decreases in ATP may result in cytochrome $c$ release and thus may evoke PCD and losses in aged seed viability.

Observations made by El-Maarouf-Bouteau et al. (2011) show that PCD is found in hydrated seed states during the aging process. They proposed a scenario in which ROS together with by-products of lipid peroxidation trigger PCD in artificially aged seeds via DNA damaging (DNA laddering) and impaired mitochondrial functions. Associations with ROS and PCD were also found through CDT treatments applied to elm seeds (Ulmus pumila; Hu et al., 2012; Wang et al., 2015a). Transcriptional studies on aged pea seeds show that during the aging process, PCD-related and antioxidant gene expression levels change, leading to the progression of PCD and to the reduction of antioxidant capacity, which in turn eventually contribute to a loss of seed viability (Chen et al., 2013). Nevertheless, the impairment of seed viability by ROS-initiated PCD during aging has not been fully elucidated and requires further examination. 
Some reports have shown that seed priming contributes to the alleviation of deleterious effects of seed aging (Bailly et al., 1998; Chiu et al., 2002; Goel et al., 2003; Butler et al., 2009). Priming with water and ascorbic acid improves the germination percentage of artificially aged cotton seeds concomitant with the lowering of lipid peroxidation and the partial restoration of antioxidant enzyme activities (CAT, SOD, POD, and GR in particular; Goel et al., 2003). Kibinza et al. (2011) showed that osmopriming applied after the artificial aging of sunflower seeds improves germination percentages independent of the aging period. Similarly, osmopriming leads to a significant drop in $\mathrm{H}_{2} \mathrm{O}_{2}$ and to the reestablishment of both catalase activity and CAT1 transcript content. Their analysis of in situ CAT localization showed that this enzyme is also found with $\mathrm{H}_{2} \mathrm{O}_{2}$ in the cytosolic area. The authors concluded that CAT is a pivotal enzyme that protects against damages caused by ROS activities in aged seeds subjected to priming treatments (Kibinza et al., 2011).

\section{CONCLUSION AND PERSPECTIVES}

Seeds are of fundamental importance to plants as a means of propagation, and thus germination constitutes a critical phase as seeds transition from dormant to metabolically active states through to growth commencement and further development. Seeds are also exceedingly important to humans due to their function as a major source of crop production. As seeds are evidently of great biological and economic importance, precise knowledge of combined environmental and endogenous signals that regulate germination capacities are of great importance. Numerous studies have been conducted on cultivated plants for agricultural and economic purposes and on model plants (mainly Arabidopsis) for understanding cellular, biochemical and molecular processes that affect dormancy and germination. Crosstalk between the $\mathrm{H}_{2} \mathrm{O}_{2}$ signaling pathway and other signaling molecules such as $\mathrm{NO}$ and $\mathrm{H}_{2} \mathrm{~S}$ and phytohormones such as ABA, GA, and ET play an integrative role in switches made between dormant and germinated states (Figure 2). The

\section{REFERENCES}

Abass, S. M., and Mohamed, H. I. (2011). Alleviation of adverse effects of drought stress on common bean (Phaseolus vulgaris L.) by exogenous application of hydrogen peroxide. Bangladesh J. Bot. 41, 75-83.

Ahmad, I., Basra, M. S. A., Hussain, S., Hussain, S. A., Rehman, H. U., Rehman, A., et al. (2015). Priming with ascorbic acid, salicylic acid and hydrogen peroxide improves seedling growth of spring maize at suboptimal temperature. J. Environ. Agric. Sci. 3, 14-22.

Arc, E., Galland, M., Godin, B., Cueff, G., and Rajjou, L. (2013a). Nitric oxide implication in the control of seed dormancy and germination. Front. Plant Sci. 4:346. doi: 10.3389/fpls.2013.00346

Arc, E., Sechet, J., Corbineau, F., Rajjou, L., and Marion-Poll, A. (2013b). ABA crosstalk with ethylene and nitric oxide in seed dormancy and germination. Front. Plant Sci. 4:63. doi: 10.3389/fpls.2013.00063

Arc, E., Ogé, L., Grappin, P., and Rajjou, L. (2011). "Plant seed: a relevant model to study aging processes," in The Field of Biological Aging: Past, Present and Future, ed. A. Olgun (Kerala: Transworld Research Network), $87-102$. accumulation of $\mathrm{H}_{2} \mathrm{O}_{2}$ and of other ROS during storage facilitates germination and has deleterious effects on seed viability.

It has been shown that pre-sown seed priming can be applied to improve seed quality, resulting in better germination performance and higher vigor while partially abolishing seed aging effects. Priming also influences signaling pathways through interactions with $\mathrm{H}_{2} \mathrm{O}_{2}$ metabolism (Figure 3). The exact mechanisms and functions of $\mathrm{H}_{2} \mathrm{O}_{2}$ during the germination of primed seeds must be clarified. One avenue for future research will involve identifying seed priming effects on the modulation of $\mathrm{H}_{2} \mathrm{O}_{2}$-mediated signaling networks. The use of numerous mutants and the development of new techniques will generate new perspectives that facilitate the more comprehensive explanation and substantiation of reviewed processes.

\section{AUTHOR CONTRIBUTIONS}

All of the authors have substantially contributed to the conception of this work and have jointly participated in drafting the manuscript and in preparing the figures. All of the authors critically revised the content of this work for key intellectual content and approved of its submission for publication. All of the authors have agreed to be accountable for all aspects of the work in ensuring that questions related to the accuracy or integrity of any part of the work are appropriately investigated and resolved.

\section{FUNDING}

This study on the molecular and physiological basis of seed priming as a strategy improving the stress tolerance of germinating rape seeds was conducted at the Institute of Experimental Biology Department of Plant Physiology at Adam Mickiewicz University in Poznan, Poland with financial support from National Science Centre grant no. 2011/03/B/NZ/00068 awarded to MG. Publication costs were supported through the KNOW RNA Research Center in Poznan, Poland under Project no. ZFD.74.53.2014.2.AS.

Argerich, C. A., Bradford, K. J., and Tarquis, A. M. (1989). The effects of priming and ageing on resistance to deterioration of tomato seeds. J. Exp. Bot. 40, 593-598. doi: 10.1093/jxb/40.5.593

Ashraf, M., and Foolad, M. R. (2005). Pre-sowing seed treatment - a shotgun approach to improve germination, plant growth, and crop yield under saline and non-saline conditions. Adv. Agron. 88, 223-271. doi: 10.1016/S00652113(05)88006-X

Ashraf, M. A., Rasheed, R., Hussain, I., Iqbal, M., Haider, M. Z., Parveen, S., et al. (2015). Hydrogen peroxide modulates antioxidant system and nutrient relation in maize (Zea mays L.) under water-deficit conditions. Arch. Agron. Soil Sci. 61, 507-523. doi: 10.1080/03650340.2014.938644

Bahin, E., Bailly, C., Sotta, B., Kranner, I., Corbineau, F., and Leymarie, J. (2011). Crosstalk between reactive oxygen species and hormonal signalling pathways regulates grain dormancy in barley. Plant Cell Environ. 34, 980-993. doi: 10.1111/j.1365-3040.2011.02298.x

Bailly, C. (2004). Active oxygen species and antioxidants in seed biology. Seed Sci. Res. 14, 93-107. doi: 10.1079/SSR2004159

Bailly, C., Benamar, A., Corbineau, F., and Côme, D. (1996). Changes in malondialdehyde content and in superoxide dismutase, catalase and 
glutathione reductase activities in sunflower seeds as related to deterioration during accelerated aging. Physiol. Plant. 97, 104-110. doi: 10.1111/j.13993054.1996.tb00485.x

Bailly, C., Benamar, A., Corbineau, C., and Côme, D. (1998). Free radical scavenging as affected by accelerated ageing and subsequent priming in sunflower seeds. Physiol. Plant. 104, 646-652. doi: 10.1034/j.13993054.1998.1040418.x

Bailly, C., Benamar, A., Corbineau, F., and Côme, D. (2000). Antioxidant systems in sunflower (Helianthus annuus L.) seeds as affected by priming. Seed Sci. Res. 10, 35-42. doi: 10.1016/j.plantsci.2011.06.003

Bailly, C., El-Maarouf-Bouteau, H., and Corbineau, F. (2008). From intracellular signaling networks to cell death: the dual role of reactive oxygen species in seed physiology. C. R. Biol. 331, 806-814. doi: 10.1016/j.crvi.2008.07.022

Balestrazzi, A., Confalonieri, M., Macovei, A., and Carbonera, D. (2011). Seed imbibition in Medicago truncatula Gaertn. Expression profiles of DNA repair genes in relation to PEG-mediated stress. J. Plant Physiol. 168, 706-713. doi: 10.1016/j.jplph.2010.10.008

Barba-Espín, G., Diaz-Vivancos, P., Clemente-Moreno, M. J., Albacete, A., Faize, L., Faize, M., et al. (2010). Interaction between hydrogen peroxide and plant hormones during germination and the early growth of pea seedlings. Plant Cell Environ. 33, 981-994. doi: 10.1111/j.1365-3040.2010.02120.x

Barba-Espín, G., Diaz-Vivancos, P., Job, D., Belghazi, M., Job, C., and Hernández, J. A. (2011). Understanding the role of $\mathrm{H} 2 \mathrm{O} 2$ during pea seed germination: a combined proteomic and hormone profiling approach. Plant Cell Environ. 34, 1907-1919. doi: 10.1111/j.1365-3040.2011.02386.x

Barba-Espín, G., Hernández, J. A., and Diaz-Vivancos, P. (2012). Role of H2O2 in pea seed germination. Plant Signal. Behav. 7, 193-195. doi: 10.4161/psb.18881

Bazin, J., Langlade, N., Vincourt, P., Arribat, S., Balzergue, S., El-MaaroufBouteau, H., et al. (2011). Targeted mRNA oxidation regulates sunflower seed dormancy alleviation during dry after-ripening. Plant Cell 23, 2196-2208. doi: 10.1105/tpc.111.086694

Bellani, L. M., Salvini, L., Dell'Aquila, A., and Scialabba, A. (2012). Reactive oxygen species release, vitamin E, fatty acid and phytosterol content of artificially aged radish (Raphanus sativus L.) seeds during germination. Acta Physiol. Plant. 34, 1789-1799. doi: 10.1007/s11738-012-0976-0

Bentsik, L., and Koornneef, M. (2008). Seed dormancy and germination. Arabidopsis Book 6, e0119. doi: 10.1199/tab.0119

Bethke, P. C., Gubler, F., Jacobsen, J. V., and Jones, R. L. (2004). Dormancy of Arabidopsis seeds and barley grains can be broken by nitric oxide. Planta 219, 847-855. doi: 10.1007/s00425-004-1282-x

Bethke, P. C., Libourel, I. G. L., and Jones, R. L. (2006). Nitric oxide reduces seed dormancy in Arabidopsis. J. Exp. Bot. 57, 517-526. doi: 10.1093/jxb/erj060

Bewley, J. D., Bradford, K. J., Hilhorst, H. M. W., and Nonogaki, H. (2013). Seeds: Physiology of Development, Germination and Dormancy. New York, NY: Springer.

Black, M., Bewley, J. D., and Halmer, P. (2006). The Encyclopedia of Seeds: Science, Technology and Uses. Wallingford: CABI.

Bolwell, G. P., and Wojtaszek, P. (1997). Mechanisms for the generation of reactive oxygen species in plant defence - a broad perspective. Physiol. Mol. Plant Pathol. 51, 347-366. doi: 10.1006/pmpp.1997.0129

Bradford, K. J. (1986). Manipulation of seed water relations via osmotic priming to improve germination under stress conditions. HortScience 21, 1105-1112.

Brady, S. M., and McCourt, P. (2003). Hormone cross-talk in seed dormancy. J. Plant Growth Regul. 22, 25-31. doi: 10.1007/s00344-003-0018-7

Bruce, T. J. A., Matthes, M. C., Napier, J. A., and Pickett, J. A. (2007). Stressful "memories" of plants: evidence and possible mechanisms. Plant Sci. 173, 603608. doi: 10.1016/j.plantsci.2007.09.002

Butler, L. H., Hay, F. R., Ellis, R. H., Smith, R. D., and Murray, T. B. (2009). Priming and re-drying improve the survival of mature seeds of Digitalis purpurea during storage. Ann. Bot. 103, 785-794. doi: 10.1093/aob/mcp059

Bykova, N. V., Hoehn, B., Rampitsch, C., Banks, T., Stebbing, J.-A., Fan, T., et al. (2011a). Redox-sensitive proteome and antioxidant strategies in wheat seed dormancy control. Proteomics 11, 865-882. doi: 10.1002/pmic.200900810

Bykova, N. V., Hoehn, B., Rampitsch, C., Hu, J. J., Stebbing, J. A., and Knox, R. (2011b). Thiol redox-sensitive seed proteome in dormant and nondormant hybrid genotypes of wheat. Phytochemistry 72, 1162-1172. doi: 10.1016/j.phytochem.2010.12.021
Cakmak, T., Atici, O., Agar, G., and Sunar, S. (2010). Natural aging-related biochemical changes in alfalfa (Medicago sativa L.) seeds stored for 42 years. Int. Res. J. Plant Sci. 1, 1-6.

Calderwood, A., and Kopriva, S. (2014). Hydrogen sulfide in plants: from dissipation of excess sulfur to signaling molecule. Nitric Oxide 41, 72-78. doi: 10.1016/j.niox.2014.02.005

Cao, J., Lv, X. Y., Chen, L., Xiang, J. J., and Lan, H. Y. (2015). Effects of salinity on the growth, physiology and relevant gene expression of an annual halophyte grown from heteromorphic seeds. AoB Plants 7, plv112. doi: 10.1093/aobpla/plv112

Catusse, J., Strub, J. M., Job, C., Van Dorsselaer, A., and Job, D. (2008). Proteomewide characterization of sugarbeet seed vigor and its tissue specific expression. Proc. Natl. Acad. Sci. U.S.A. 105, 10262-10267. doi: 10.1073/pnas.0800 585105

Cavusoglu, K., and Kabar, K. (2010). Effects of hydrogren peroxide on the germination and early seedling growth of barley under $\mathrm{NaCl}$ and high temperature stresses. Eurasia J. Biosci. 4, 70-79. doi: 10.5053/ejobios.2010. 4.0.9

Chaudhuri, A., Singh, K. L., and Kar, R. K. (2013). Interaction of hormones with reactive oxygen species in regulating seed germination of Vigna radiata (L.) Wilczek. J. Plant Biochem. Physiol. 1, 103. doi: 10.4172/jpbp.1000103

Chen, H. Y., Osuna, D., Colville, L., Lorenzo, O., Graeber, K., Küster, H., et al. (2013). Transcriptome-Wide mapping of pea seed ageing reveals a pivotal role for genes related to oxidative stress and programmed cell death. PLoS ONE 8:e78471. doi: 10.1371/journal.pone.0078471

Chen, K., and Arora, R. (2011). Dynamics of the antioxidant system during seed osmopriming, post-priming germination, and seedling establishment in spinach (Spinacia oleracea). Plant Sci. 180, 212-220. doi: $10.1016 /$ j.plantsci.2010.08.007

Chen, K., and Arora, R. (2013). Priming memory invokes seed stress-tolerance. Environ. Exp. Bot. 94, 33-45. doi: 10.1016/j.jprot.2013.08.010

Chen, K., Fessehaie, A., and Arora, R. (2012). Dehydrin metabolism is altered during seed osmopriming and subsequent germination under chilling and desiccation in Spinacia oleracea L. cv. Bloomsdale: possible role in stress tolerance. Plant Sci. 183, 27-36. doi: 10.1016/j.plantsci.2011.11.002

Chinnusamy, V., and Zhu, J.-K. (2009). Epigenetic regulation of stress responses in plants. Curr. Opin. Plant Biol. 12, 1-7. doi: 10.1016/j.pbi.2008.12.006

Chiu, K. Y., Chen, C. L., and Sung, J. M. (2002). Effect of priming temperature on storability of primed sh-2 sweet corn seed. Crop Sci. 42, 1996-2003. doi: $10.2135 /$ cropsci2002.1996

Chmielowska-Bąk, J., Izbiańska, K., and Deckert, J. (2015). Products of lipid, protein and mRNA oxidation as signals and regulators of gene expression. Front. Plant Sci. 6:405. doi: 10.3389/fpls.2015.00405

Coll, N. S., Epple, P., and Dang, J. L. (2011). Programmed cell death in the plant immune system. Cell Death Differ. 18, 1247-1256. doi: 10.1038/cdd.2011.37

Corbineau, F., Xia, Q., Bailly, C., and El-Maarouf-Bouteau, H. (2014). Ethylene, a key factor in the regulation of seed dormancy. Front. Plant Sci. 5:539. doi: $10.3389 /$ fpls.2014.00539

Daszkowska-Golec, A. (2011). Arabidopsis seed germination under abiotic stress as a concert of action of phytohormones. OMICS 15, 763-774. doi: 10.1089/omi.2011.0082

Davies, M. J. (2005). The oxidative environment and protein damage. Biochim. Biophys. Acta 1703, 93-109. doi: 10.1016/j.bbapap.2004.08.007

Di Girolamo, G., and Barbanti, L. (2012). Treatment conditions and biochemical processes influencing seed priming effectiveness. Ital. J. Agron. 7, 8-18.

Diaz-Vivancos, P., Barba-Espín, G., and Hernández, J. A. (2013). Elucidating hormonal/ROS networks during seed germination: insights and perspectives. Plant Cell Rep. 32, 1491-1502. doi: 10.1007/s00299-013-1473-7

Dooley, F. D., Nair, S. P., and Ward, P. D. (2013). Increased growth and germination success in plants following hydrogen sulfide administration. PLoS ONE 8:e62048. doi: 10.1371/journal.pone.0062048

El-Araby, M. M., Moustafa, S. M. A., Ismail, A. I., and Hegazi, A. Z. A. (2006). Hormone and phenol levels during germination and osmopriming of tomato seeds, and associated variations in protein patterns and anatomical seed features. Acta Agron. Hung. 54, 441-458. doi: 10.1556/AAgr.54.2006.4.7

El-Maarouf-Bouteau, H., and Bailly, C. (2008). Oxidative signaling in seed germination and dormancy. Plant Signal. Bechav. 3, 175-182. doi: $10.4161 / \mathrm{psb} .3 .3 .5539$ 
El-Maarouf-Bouteau, H., Mazuy, C., Corbineau, F., and Bailly, C. (2011). DNA alteration and programmed cell death during ageing of sunflower seed. J. Exp. Bot. 62, 5003-5011. doi: 10.1093/jxb/err198

El-Maarouf-Bouteau, H., Meimoun, P., Job, C., Job, D., and Bailly, C. (2013). Role of protein and mRNA oxidation in seed dormancy and germination. Front. Plant Sci. 4:77. doi: 10.3389/fpls.2013.00077

El-Maarouf-Bouteau, H., Sajjad, Y., Bazin, J., Langlade, N., Cristescu, S. M., Balzergue, S., et al. (2015). Reactive oxygen species, abscisic acid and ethylene interact to regulate sunflower seed germination. Plant Cell Environ. 38, 364374. doi: $10.1111 /$ pce. 12371

Farooq, M., Wahid, A., Ahmad, N., and Asad, S. A. (2010). Comparative efficacy of surface drying and re-drying seed priming in rice: changes in emergence, seedling growth and associated metabolic events. Paddy Water Environ. 8, 15-22. doi: 10.1007/s10333-009-0170-1

Fath, A., Bethke, P., Beligni, V., and Jones, R. (2002). Active oxygen and cell death in cereal aleurone cells. J. Exp. Bot. 53, 1273-1282. doi: 10.1093/jexbot/53.372.1273

Finch-Savage, W. E., and Leubner-Metzger, G. (2006). Seed dormancy and the control of germination. New Phytol. 171, 501-523. doi: 10.1111/j.14698137.2006.01787.x

Finkelstein, R., Reeves, W., Ariizumi, T., and Steber, C. (2008). Molecular aspects of seed dormancy. Annu. Rev. Plant Biol. 59, 387-415. doi: 10.1146/annurev.arplant.59.032607.092740

Fu, Y. B., Ahmed, Z., and Diederichsen, A. (2015). Towards a better monitoring of seed ageing under ex situ seed conservation. Conserv. Physiol. 3, 26. doi: $10.1093 /$ conphys/cov026

Gadjev, I., Stone, J. M., and Gechev, T. S. (2008). Programmed cell death in plants: new insights into redox regulation and the role of hydrogen peroxide. Int. Rev. Cell Mol. Biol. 270, 87-144. doi: 10.1016/S1937-6448(08)01403-2

Gallardo, K., Job, C., Groot, S. P. C., Puype, M., Demol, H., Vandekerekhove, J., et al. (2001). Proteomic analysis of Arabidopsis seed germination and priming. Plant Physiol. 126, 835-848. doi: 10.1104/pp.126.2.835

Gao, Y.-P., Young, L., Bonham-Smith, P., and Gusta, L. V. (1999). Characterization and expression of plasma and tonoplast membrane aquaporins in primed seeds of Brassica napus during germination under stress conditions. Plant Mol. Biol. 40, 635-644. doi: 10.1023/A:1006212216876

Gidrol, X., Lin, W. S., Degousee, N., Yip, S. F., and Kush, A. (1994). Accumulation of reactive oxygen species and oxidation of cytokinin in germinating soybean seeds. Eur. J. Biochem. 224, 21-28. doi: 10.1111/j.1432-1033.1994.tb19990.x

Gniazdowska, A., Krasuska, U., and Bogatek, R. (2010a). Dormancy removal in apple embryos by nitric oxide or cyanide involves modifications in ethylene biosynthetic pathway. Planta 232, 1397-1407. doi: 10.1007/s00425-0101262-2

Gniazdowska, A., Krasuska, U., Debska, K., Andryka, P., and Bogatek, R. (2010b). The beneficial effect of small toxic molecules on dormancy alleviation and germination of apple embryos is due to NO formation. Planta 232, 999-1005. doi: 10.1007/s00425-010-1214-x

Gniazdowska, A., Krasuska, U., Czajkowska, K., and Bogatek, R. (2010c). Nitric oxide, hydrogen cyanide and ethylene are required in the control of germination and undisturbed development of young apple seedlings. Plant Growth Regul. 61, 75-84. doi: 10.1007/s10725-010-9452-2

Goel, A., Goel, A. K., and Sheoran, I. S. (2003). Changes in oxidative stress enzymes during artificial ageing in cotton (Gossypium hirsutum L.) seeds. J. Plant Physiol. 160, 1093-1100. doi: 10.1078/0176-1617-00881

Goel, A., and Sheoran, I. S. (2003). Lipid peroxidation and peroxide-scavenging enzymes in cotton seeds under natural ageing. Biol. Plant. 46, 429-434. doi: 10.1023/A:1024398724076

Golldack, D., Li, C., Mohan, H., and Probst, N. (2013). Gibberellins and abscisic acid signal crosstalk: living and developing under unfavorable conditions. Plant Cell Rep. 32, 1007-1016. doi: 10.1007/s00299-013-1409-2

Graeber, K., Nakabayashi, K., Miatton, E., Leubner-Metzgber, G., and Soppe, W. J. J. (2012). Molecular mechanisms of seed dormancy. Plant Cell Environ. 35, 1769-1786. doi: 10.1111/j.1365-3040.2012.02542.x

Groot, S. P. C., Surki, A. A., de Vos, R. C. H., and Kodde, J. (2012). Seed storage at elevated partial pressure of oxygen, a fast method for analysing seed ageing under dry conditions. Ann. Bot. 110, 1149-1159. doi: 10.1093/aob/mcs198

Guan, C., Wang, X., Feng, J., Hong, S., Liang, Y., Ren, B., et al. (2014). Cytokinin antagonizes abscisic acid-mediated inhibition of cotyledon greening by promoting the degradation of abscisic acid insensitive5 protein in Arabidopsis. Plant Physiol. 164, 1515-1526. doi: 10.1104/pp.113.234740

Hancock, J. T., and Whiteman, M. (2014). Hydrogen sulfide and cell signaling: team player or referee? Plant Physiol. Biochem. 78, 37-42. doi: 10.1016/j.plaphy.2014.02.012

Hancock, J. T., and Whiteman, M. (2015). Hydrogen sulfide signaling: interactions with nitric oxide and reactive oxygen species. Ann. N. Y. Acad. Sci. doi: 10.1111/nyas.12733 [Epub ahead of print].

He, L., Gao, Z., and Li, R. (2009). Pretreatment of seed with H2O2 enhances drought tolerance of wheat seedlings. Afr. J. Biotechnol. 8, 6151-6157.

Hilhorst, H. W. M., Finch-Savage, W. E., Buitink, J., Bolingue, W., and LeubnerMetzger, G. (2010). "Dormancy in plant seeds," in Dormancy and Resistance in Harsh Environments, eds E. Lubzens, J. Cerdà, and M. Clarck (Heideberg: Springer-Verlag), 43-67.

Hossain, M. A., Bhattacharjee, S., Armin, S.-M., Qian, P., Xin, W., Li, H.-Y., et al. (2015). Hydrogen peroxide priming modulates abiotic oxidative stress tolerance: insights from ROS detoxification and scavenging. Front. Plant Sci. 6:420. doi: 10.3389/fpls.2015.00420

Hu, D., Ma, G., Wang, Q., Yao, J., Pritchard, H. W., and Wang, X. (2012). Spatial and temporal nature of reactive oxygen species production and programmed cell death in elm (Ulmus pumila L.) seeds during controlled deterioration. Plant Cell Environ. 35, 2045-2059. doi: 10.1111/j.1365-3040.2012.02535.x

Hussain, I., Ahmad, R., Farooq, M., and Wahid, A. (2014). Seed priming improves the performance of poor quality wheat seed. Int. J. Agric. Biol. 15, 1343-1348.

Hussain, S., Zheng, M., Khan, F., Khaliq, A., Fahad, S., Peng, S., et al. (2015). Benefits of rice seed priming are offset permanently by prolonged storage and the storage conditions. Sci. Rep. 5, 8101. doi: 10.1038/srep08101

Iqbal, M., and Ashraf, M. (2006). Wheat seed priming in relation to salt tolerance: growth, yield and levels of free salicylic acid and polyamines. Ann. Bot. Fennici 43, 250-259.

Iqbal, M., and Ashraf, M. (2007). Seed preconditioning modulates growth, ionic relations, and photosynthetic capacity in adult plants of hexaploid wheat under salt stress. J. Plant Nutr. 30, 381-396. doi: 10.1080/01904160601171330

Ishibashi, Y., Koda, Y., Zheng, S.-H., Yuasa, T., and Iwaya-Inoue, M. (2013). Regulation of soybean seed germination through ethylene production in response to reactive oxygen species. Ann. Bot. 111, 95-102. doi: $10.1093 / \mathrm{aob} / \mathrm{mcs} 240$

Ishibashi, Y., Tawaratsumida, T., Kondo, K., Kasa, S., Sakamoto, M., Aoki, N., et al. (2012). Reactive oxygen species are involved in gibberellin/abscisic acid signaling in barley aleurone cells. Plant Physiol. 158, 1705-1714. doi: $10.1104 / \mathrm{pp} .111 .192740$

Jin, Z., and Pei, Y. (2015). Physiological implications of hydrogen sulfide in plants: pleasant exploration behind its unpleasant odour. Oxid. Med. Cell. Longev. 2015, 397502. doi: 10.1155/2015/397502

Jisha, K. C., and Puthur, J. T. (2015). Seed priming with BABA ( $\beta$-amino butyric acid): a cost-effective method of abiotic stress tolerance in Vigna radiata (L.) Wilczek. Protoplasma doi: 10.1007/s00709-015-0804-7 [Epub ahead of print].

Jisha, K. C., Vijayakumari, K. J. T., and Puthur, J. T. (2013). Seed priming for abiotic stress tolerance: an overview. Acta Physiol. Plant. 3, 1381-1396. doi: 10.1007/s11738-012-1186-5

Job, C., Rajjou, L., Lovigny, Y., Belghazi, M., and Job, D. (2005). Patterns of protein oxidation in Arabidopsis seeds and during germination. Plant Physiol. 138, 790-802. doi: 10.1104/pp.105.062778

Kalemba, E. M., Suszka, J., and Ratajczak, E. (2015). The role of oxidative stress in determining the level of viability of black poplar (Populus nigra) seeds stored at different temperatures. Funct. Plant Biol. 42, 630-642. doi: 10.1071/FP14336

Khan, T. A., Yusuf, M., and Fariduddin, Q. (2015). Seed treatment with $\mathrm{H} 2 \mathrm{O} 2$ modifies net photosynthetic rate and antioxidant system in mung bean (Vigna radiata L. Wilczek) plants. Isr. J. Plant Sci. 62, 167-175. doi: 10.1080/07929978.2015.1060806

Kibinza, S., Bazin, J., Bailly, C., Farrant, J. M., Corbineau, F., and El-MaaroufBouteau, H. (2011). Catalase is a key enzyme in seed recovery from ageing during priming. Plant Sci. 181, 309-315. doi: 10.1016/j.plantsci.2011. 06.003

Kibinza, S., Vinel, D., Côme, D., Bailly, C., and Corbineau, F. (2006). Sunflower seed deterioration as related to moisture content during aging, energy metabolism and active oxygen species scavenging. Physiol. Plant. 128, 496-506. doi: 10.1111/j.1399-3054.2006.00771.x 
Kong, L., Huo, H., and Mao, P. (2015). Antioxidant response and related gene expression in aged oat seed. Front. Plant Sci. 6:158. doi: 10.3389/fpls.2015.00158

Kong, Q. M., and Lin, C. G. (2010). Oxidative damage to RNA: mechanisms, consequences and diseases. Cell. Mol. Life Sci. 67, 1817-1829. doi: 10.1007/s00018-010-0277-y

Kopyra, M., and Gwóźdź, E. A. (2003). Nitric oxide stimulates seed germination and counteracts the inhibitory effect of heavy metals and salinity on root growth of Lupinus luteus. Plant Physiol. Biochem. 41, 1011-1017. doi: 10.1016/j.plaphy.2003.09.003

Kranner, I., Chen, H. Y., Pritchard, H. W., Pearce, S. R., and Birtic, S. (2011). Seed ageing correlates with inter-nucleosomal DNA fragmentation and loss of RNA integrity. Plant Growth Regul. 63, 63-72. doi: 10.1007/s10725-010-9512-7

Kranner, I., Roach, T., Beckett, R. P., Whitaker, C., and Minibayeva, F. V. (2010). Extracellular production of reactive oxygen species during seed germination and early seedling growth in Pisum sativum. J. Plant Physiol. 167, 805-811. doi: 10.1016/j.jplph.2010.01.019

Kranner, I., and Seal, C. E. (2013). Salt stress, signalling and redox control in seeds. Funct. Plant Biol. 40, 848-859.

Krasuska, U., Ciacka, K., Andryka-Dudek, P., Bogatek, R., and Gniazdowska, A. (2015). "“Nitrosative door" in seed dormancy alleviation and germination," in Reactive Oxygen and Nitrogen Species Signaling and Communication in Plants, eds K. J. Gupta and A. U. Igamberdiev (Cham: Springer International Publishing Switzerland), 215-237.

Krasuska, U., and Gniazdowska, A. (2012). Nitric oxide and hydrogen cyanide as regulating factors of enzymatic antioxidant system in germinating apple embryos. Acta Physiol. Plant. 34, 683-692. doi: 10.1007/s11738-011$0868-8$

Kubala, S., Garnczarska, M., Wojtyla, Ł, Clippe, A., Kosmala, A., Żmieńko, A., et al. (2015a). Deciphering priming-induced improvement of rapeseed (Brassica napus L.) germination through an integrated transcriptomic and proteomic approach. Plant Sci. 231, 94-113. doi: 10.1016/j.plantsci.2014.11.008

Kubala, S., Wojtyla, Ł, Quinet, M., Lechowska, K., Lutts, S., and Garnczarska, M. (2015b). Enhanced expression of the proline synthesis gene P5CSA in relations to seed osmopriming improvement of Brassica napus germination under salinity stress. J. Plant Physiol. 183, 1-12. doi: 10.1016/j.jplph.2015. 04.009

Kucera, B., Cohn, M. A., and Leubner-Metzger, G. (2005). Plant hormone interactions during seed dormancy release and germination. Seed Sci. Res. 15, 281-307. doi: 10.1079/SSR2005218

Kulik, A., Wawer, I., Krzywińska, E., Bucholc, M., and Dobrowolska, G. (2011). SnRK2 protein kinases - key regulators of plant response to abiotic stresses. OMICS 15, 859-872. doi: 10.1089/omi.2011.0091

Kumar, S. P. J., Prasad, S. R., Banerjee, R., and Thammineni, C. (2015). Seed birth to death: dual functions of reactive oxygen species in seed physiology. Ann. Bot. 116, 663-668. doi: 10.1093/aob/mcv098

Lariguet, P., Ranocha, P., De Meyer, M., Barbier, O., Penel, C., and Dunand, C. (2013). Identification of a hydrogen peroxide signalling pathway in the control of light-dependent germination in Arabidopsis. Planta 238, 381-395. doi: 10.1007/s00425-013-1901-5

Lehner, A., Mamadou, N., Poels, P., Côme, D., Bailly, C., and Corbineau, F. (2008). Changes in soluble carbohydrates, lipid peroxidation and antioxidant enzyme activities in the embryo during ageing in wheat grains. J. Cereal Sci. 47, 555-565. doi: 10.1016/j.jcs.2007.06.017

Li, W., Liu, X., Khan, M. A., and Yamaguchi, S. (2005). The effect of plant growth regulators, nitric oxide, nitrate, nitrite and light on the germination of dimorphic seeds of Suaeda salsa under saline conditions. J. Plant Res. 118, 207-214. doi: 10.1007/s10265-005-0212-8

Li, X., Yang, Y. Q., Zhang, M., and Wang, X. F. (2010). Effect of PEG priming on plasma membrane $\mathrm{H}+$-ATPase activities and mitochondrium function in soybean seeds. Seed Sci. Technol. 38, 49-60. doi: 10.15258/sst.2010.38.1.05

Li, Z. G. (2013). Hydrogen sulfide: a multifunctional gaseous molecule in plants. Rus. J. Plant Physiol. 60, 733-740. doi: 10.1134/S1021443713060058

Li, Z.-G., Gong, M., and Liu, P. (2012). Hydrogen sulfide is a mediator in $\mathrm{H} 2 \mathrm{O} 2$-induced seed germination in Jatropha curcas. Acta Physiol. Plant. 34, 2207-2213. doi: 10.1007/s11738-012-1021-Z

Li, Z.-G., and He, Q.-Q. (2015). Hydrogen peroxide might be a downstream signal molecule of hydrogen sulfide in seed germination of mung bean (Vigna radiata). Biologia 70, 753-759. doi: 10.1515/biolog-2015-0083
Linkies, A., and Leubner-Metzger, G. (2012). Beyond gibberellins and abscisic acid: how ethylene and jasmonates control seed germination. Plant Cell Rep. 31, 253-270. doi: 10.1007/s00299-011-1180-1

Linkies, A., Müller, K., Morris, K., Turečková, V., Wenk, M., Cadman, C. S. C., et al. (2009). Ethylene interacts with abscisic acid to regulate endosperm rupture during germination: a comparative approach using Lepidium sativum and Arabidopsis thaliana. Plant Cell 21, 3803-3822. doi: 10.1105/tpc.109.070201

Liu, P.-P., Montgomery, T. A., Fahlgren, N., Kasschau, K. D., Nonogaki, H., and Carrington, J. C. (2007). Repression of AUXIN RESPONSE FACTOR10 by microRNA160 is critical for seed germination and post-germination stages. Plant J. 52, 133-146. doi: 10.1111/j.1365-313X.2007.03218.x

Liu, W.-Z., Kong, D.-D., Gu, X.-X., Gao, H. B., Wang, J.-Z., Xia, M., et al. (2013). Cytokinins can act as suppressors of nitric oxide in Arabidopsis. Proc. Natl. Acad. Sci. U.S.A. 110, 1548-1553. doi: 10.1073/pnas.1213235110

Liu, Y., Ye, N., Liu, R., Chen, M., and Zhang, J. (2010). H2O2 mediates the regulation of ABA catabolism and GA biosynthesis in Arabidopsis seed dormancy and germination. J. Exp. Bot. 61, 2979-2990. doi: 10.1093/jxb/erq125

Luna, E., and Ton, J. (2012). The epigenetic machinery controlling transgenerational systemic acquired resistance. Plant Signal. Behav. 7, 615-618. doi: 10.4161/psb.20155

Mastouri, F., Björkman, T., and Harman, G. E. (2010). Seed treatment with Trichoderma harzianum alleviates biotic, abiotic, and physiological stresses in germinating seeds and seedlings. Biol. Control 100, 1213-1221. doi: 10.1094/PHYTO-03-10-0091

Matilla, A. J., and Matilla-Vázquez, M. A. (2008). Involvement of ethylene in seed physiology. Plant Sci. 175, 87-97. doi: 10.1016/j.plantsci.2008.01.014

McDonald, M. B. (1999). Seed deterioration: physiology, repair and assessment. Seed Sci. Technol. 27, 177-237.

Miransari, M., and Smith, D. L. (2014). Plant hormones and seed germination. Environ. Exp. Bot. 99, 110-121. doi: 10.1016/j.envexpbot.2013.11.005

Møller, I. M., Jensen, P. E., and Hansson, A. (2007). Oxidative modifications to cellular components in plants. Ann. Rev. Plant Biol. 58, 459-481. doi: 10.1146/annurev.arplant.58.032806.103946

Morkunas, I., Bednarski, W., and Kozłowska, M. (2004). Response of embryo axes of germinating seeds of yellow lupine to Fusarium oxysporum. Plant Physiol. Biochem. 42, 493-499. doi: 10.1016/j.plaphy.2004.05.007

Morscher, F., Kranner, I., Arc, E., Bailly, C., and Roach, T. (2015). Glutathione redox state, tocochromanols, fatty acids, antioxidant enzymes and protein carbonylation in sunflower seed embryos associated with after-ripening and ageing. Ann. Bot. 116, 669-678. doi: 10.1093/aob/mcv108

Müller, K., Hess, B., and Leubner-Metzger, G. (2007). "A role for reactive oxygen species in endosperm weakening," in Seeds: Biology, Development and Ecology, eds S. Adkins, S. Ashmore, and S. Navie (Wallingford: CAB International), 287-295.

Müller, K., Tintelnot, S., and Leubner-Metzger, G. (2006). Endospermlimited Brassicaceae seed germination: abscisic acid inhibits embryo-induced endosperm weakening of Lepidium sativum (cress) and endosperm rupture of cress and Arabidopsis thaliana. Plant Cell Physiol. 47, 864-877. doi: 10.1093/pcp/pcj059

Murthy, U. M. N., Kumar, P. P., and Sun, W. Q. (2003). Mechanisms of seed ageing under different storage conditions for Vigna radiate (L.) Wilczek: lipid peroxidation, sugar hydrolysis. J. Exp. Bot. 54, 1057-1067. doi: $10.1093 / \mathrm{jxb} / \mathrm{erg} 092$

Nakashima, K., Fujita, Y., Kanamori, N., Katagiri, T., Umezawa, T., Kidokoro, S., et al. (2009). Three Arabidopsis SnRK2 protein kinases, SRK2D/SnRK2.2, SRK2E/SnRK2.6/OST1 and SRK2I/SnRK2.3, involved in ABA signaling are essential for the control of seed development and dormancy. Plant Cell Physiol. 50, 1345-1363. doi: 10.1093/pcp/pcp083

Nambara, E., Okamoto, M., Tatematsu, K., Yano, R., Seo, M., and Kamiya, Y. (2010). Abscisic acid and the control of seed dormancy and germination. Seed Sci. Res. 20, 55-67. doi: 10.1017/S0960258510000012

Nonogaki, H., Bassel, G. W., and Bewley, J. D. (2010). Germination - still a mystery. Plant Sci. 179, 574-581. doi: 10.4161/psb.25504

Oracz, K., El-Maarouf-Bouteau, H., Bogatek, R., Corbineau, F., and Bailly, C. (2008). Release of sunflower seed dormancy by cyanide: cross-talk with ethylene signalling pathway. J. Exp. Bot. 59, 2241-2251. doi: 10.1093/jxb/ern089

Oracz, K., El-Maarouf-Bouteau, H., Farrant, J. M., Cooper, K., Belghazi, M., Job, C., et al. (2007). ROS production and protein oxidation as a novel mechanism 
for seed dormancy alleviation. Plant J. 50, 452-465. doi: 10.1111/j.1365313X.2007.03063.x

Oracz, K., El-Maarouf-Bouteau, H., Kranner, I., Bogatek, R., Corbineau, F., and Bailly, C. (2009). The mechanisms involved in seed dormancy alleviation by hydrogen cyanide unravel the role of reactive oxygen species as key factors of cellular signaling during germination. Plant Physiol. 150, 494-505. doi: 10.1104/pp.109.138107

Paparella, S., Araújo, S. S., Rossi, G., Wijayasinghe, M., Carbonera, D., and Balestrazzi, A. (2015). Seed priming: state of the art and new perspectives. Plant Cell Rep. 34, 1281-1293. doi: 10.1007/s00299-015-1784-y

Parkhey, S., Naithani, S. C., and Keshavkant, S. (2012). ROS production and lipid catabolism in desiccating Shorea robusta seeds during aging. Plant Physiol. Biochem. 57, 261-267. doi: 10.1016/j.plaphy.2012.06.008

Pastor, V., Luna, E., Mauch-Mani, B., Ton, J., and Flors, V. (2013). Primed plants do not forget. Environ. Exp. Bot. 94, 46-56. doi: 10.1016/j.envexpbot.2012. 02.013

Patade, V. Y., Maya, K., and Zakwan, A. (2011). Seed priming mediated germination improvement and tolerance to subsequent exposure to cold and salt stress in capsicum. Res. J. Seed Sci. 4, 125-136. doi: 10.3923/rjss.2011.125.136

Petrov, V. D., and Van Breusegem, F. (2012). Hydrogen peroxide - a central hub for information flow in plant cells. AoB Plants 2012, 1s014. doi: $10.1093 /$ aobpla/pls014

Pommier, Y., Redon, C., Rao, V. A., Seiler, J. A., Sordet, O., Takemura, H., et al. (2003). Repair of and checkpoint response to topoisomerase I-mediated DNA damage. Mutat. Res. 532, 173-203. doi: 10.1016/j.mrfmmm.2003.08.016

Posmyk, M. M., Corbineau, F., Vinel, D., Bailly, C., and Côme, D. (2001). Osmoconditioning reduces physiological and biochemical damage induced by chilling in soybean seeds. Physiol. Plant. 111, 473-483. doi: 10.1034/j.13993054.2001.1110407.x

Pukacka, S., and Ratajczak, E. (2005). Production and scavenging of reactive oxygen species in Fagus sylvatica seeds during storage at varied temperature and humidity. J. Plant Physiol. 162, 873-885. doi: 10.1016/j.jplph.2004.10.012

Pukacka, S., and Ratajczak, E. (2007). Age-related biochemical changes during storage of beech (Fagus sylvatica L.) seeds. Seed Sci. Res. 17, 45-53. doi: $10.1017 / \mathrm{S} 0960258507629432$

Rajjou, L., Duval, M., Gallardo, K., Catusse, J., Bally, J., Job, C., et al. (2012). Seed germination and vigor. Ann. Rev. Plant Biol. 63, 507-533. doi: 10.1146/annurevarplant-042811-105550

Rajjou, L., Lovigny, Y., Groot, S. P., Belghazi, M., Job, C., and Job, D. (2008). Proteome-wide characterization of seed aging in Arabidopsis: a comparison between artificial and natural aging protocols. Plant Physiol. 148, 620-641. doi: 10.1104/pp.108.123141

Ratajczak, E., Małecka, A., Bagniewska-Zadworna, A., and Kalemba, E. M. (2015). The production, localization and spreading of reactive oxygen species contributes to the low vitality of long-term stored common beech (Fagus sylvatica L.) seeds. J. Plant Physiol. 174, 147-156. doi: 10.1016/j.jplph.2014.08.021

Richards, S. L., Wilkins, K. A., Swarbreck, S. M., Anderson, A. A., Habib, N., Smith, A. G., et al. (2015). The hydroxyl radical in plants: from seed to seed. J. Exp. Bot. 66, 37-46. doi: 10.1093/jxb/eru398

Salah, S. M., Yajing, G., Dongdong, C., Jie, L., Aamir, N., Qijuan, H., et al. (2015). Seed priming with polyethylene glycol regulating the physiological and molecular mechanism in rice (Oryza sativa L.) under nano-ZnO stress. Sci. Rep. 5, 14278. doi: $10.1038 /$ srep 14278

Santhy, V., Meshram, M., Wakde, R., and Vijaja Kumari, P. R. (2014). Hydrogen peroxide pre-treatment for seed enhancement in cotton (Gossypium hirstum L.). Afr. J. Agric. Res. 9, 1982-1989. doi: 10.5897/AJAR2013.7210

Sanz, L., Albertos, P., Mateos, I., Sánchez-Vicente, I., Lechón, T., FernándezMarcos, M., et al. (2015). Nitric oxide (NO) and phytohormones crosstalk during early plant development. J. Exp. Bot. 66, 2857-2868. doi: $10.1093 /$ jxb/erv213

Sarath, G., Hou, G., Baird, L., and Mitchell, R. B. (2007a). ABA, ROS and NO are key players during switchgrass seed germination. Plant Signal. Behav. 2, 492-493. doi: 10.4161/psb.2.6.4575

Sarath, G., Hou, G., Baird, L., and Mitchell, R. B. (2007b). Reactive oxygen species, $\mathrm{ABA}$ and nitric oxide interactions on the germination of warm-season C4-grass. Planta 226, 697-708.
Schopfer, P., Plachy, C., and Frahry, G. (2001). Release of reactive oxygen intermediates (superoxide radicals, hydrogen peroxide, and hydroxyl radicals) and peroxidase in germinating radish seeds controlled by light, gibberellin, and abscisic acid. Plant Physiol. 125, 1591-1602. doi: 10.1104/pp.125.4.1591

Schwember, A. R., and Bradford, K. J. (2010). Quantitative trait loci associated with longevity of lettuce seeds under conventional and controlled deterioration storage conditions. J. Exp. Bot. 61, 4423-4436. doi: 10.1093/jxb/erq248

Slaughter, A., Daniel, X., Flors, V., Luna, E., Hohn, B., and Mauch-Mani, B. (2012). Descendants of primed Arabidopsis plants exhibit resistance to biotic stress. Plant Physiol. 158, 835-843. doi: 10.1104/pp.111.191593

Sneideris, L. C., Gavassi, M. A., Campos, M. L., D’Amico-Damião, V., and Carvalho, R. F. (2015). Effects of hormonal priming on seed germination of pigeon pea under cadmium stress. An. Acad. Bras. Cienc. 87, 1847-1852. doi: 10.1590/0001-3765201520140332

Soeda, Y., Konings, M. C. J. M., Vorst, O., van Houwelingen, A. M. M. L., Stoopen, G. M., Maliepaard, C. A., et al. (2005). Gene expression programs during Brassica oleracea seed maturation, osmopriming, and germination are indicators of progression of the germination process and the stress tolerance level. Plant Physiol. 137, 354-368. doi: 10.1104/pp.104.051664

Sun, H., Lin, L., Wang, X., Wu, S., and Wang, X. (2011). Ascorbateglutathione cycle of mitochondria in osmoprimed soybean cotyledons in response to imbibitional chilling injury. J. Plant Physiol. 168, 226-232. doi: 10.1016/j.jplph.2010.07.017

Szklarczyk, D., Franceschini, A., Wyder, S., Forslund, K., Heller, D., HuertaCepas, J., et al. (2015). STRING v10: protein-protein interaction networks, integrated over the tree of life. Nucleic Acids Res. 43, D447-D452. doi: $10.1093 /$ nar/gku1003

Tanou, G., Fotopoulos, V., and Molassiotis, A. (2012). Priming against environmental challenges and proteomics in plants: update and agricultural perspectives. Front. Plant Sci. 3:216. doi: 10.3389/fpls.2012.00216

Theerakulpisut, P., Lontom, W., Kulya, J., Bunnag, S., and Techawonstein, S. (2011). Effect of seed priming on physiological changes in tomato grown under salt stress. Acta Hortic. 914, 295-300. doi: 10.17660/ActaHortic.2011. 914.53

Van Hulten, M., Pelser, M., van Loon, L. C., Pieterse, C. M. J., and Ton, J. (2006). Costs and benefits of priming for defense in Arabidopsis. Proc. Natl. Acad. Sci. U.S.A. 103, 5602-5607. doi: 10.1073/pnas.0510213103

Ventura, L., Dona, M., Macovei, A., Carbonera, D., Buttafava, A., Mondoni, A., et al. (2012). Understanding the molecular pathways associated with seed vigor. Plant Physiol. Biochem. 60, 196-206. doi: 10.1016/j.plaphy.2012.07.031

Verma, G., Mishra, S., Sangwan, N., and Sharma, S. (2015). Reactive oxygen species mediate axis-cotyledon signaling to induce reserve mobilization during germination and seedling establishment in Vigna radiata. J. Plant Physiol. 184, 79-88. doi: 10.1016/j.jplph.2015.07.001

Wahid, A., Noreen, A., Basra, S. M. A., Gelani, S., and Farooq, M. (2008). Priminginduced metabolic changes in sunflower (Helianthus annuus) achenes improve germination and seedling growth. Bot. Stud. 49, 343-350.

Wahid, A., Parveen, M., Gelani, S., and Basra, M. S. A. (2007). Pretreatment of seeds with $\mathrm{H} 2 \mathrm{O} 2$ improves salt tolerance of wheat seedling by alleviation of oxidative damage and expression of stress proteins. J. Plant Physiol. 164, 283-294. doi: 10.1016/j.jplph.2006.01.005

Walters, C., Wheeler, L. M., and Grotenhuis, J. M. (2005). Longevity of seeds stored in a genebank: species characteristics. Seed Sci. Res. 15, 1-20. doi: $10.1079 /$ SSR2004195

Wang, Y., Li, L., Cui, W., Xu, S., Shen, W., and Wang, R. (2012a). Hydrogen sulfide enhances alfalfa (Medicago sativa) tolerance against salinity during seed germination by nitric oxide pathway. Plant Soil 351, 107-119. doi: 10.1007/s11104-011-0936-2

Wang, H.-L., Wang, L., Tian, C.-Y., and Huang, Z.-Y. (2012b). Germination dimorphism in Suaeda acuminata: a new combination of dormancy types for heteromorphic seeds. S. Afr. J. Bot. 78, 270-275. doi: 10.1016/j.sajb.2011.05.012

Wang, Y., Li, L., Ye, T., Zhao, S., Liu, Z., Feng, Y.-Q., et al. (2011). Cytokinin antagonizes ABA suppression to seed germination of Arabidopsis by downregulating ABI5 expression. Plant J. 68, 249-261. doi: 10.1111/j.1365313X.2011.04683.X

Wang, Y., Li, Y., Xue, H., Pritchard, H. W., and Wang, X. (2015a). Reactive oxygen species (ROS)-provoked mitochondria-dependent cell death during ageing of elm (Ulmus pumila L.) seeds. Plant J. 81, 438-452. doi: 10.1111/tpj.12737 
Wang, P., Zhu, J. K., and Lang, Z. (2015b). Nitric oxide suppresses the inhibitory effect of abscisic acid on seed germination by S-nitrosylation of SnRK2 proteins. Plant Signal. Behav. 10, e1031939. doi: 10.1080/15592324.2015.1031939

Weitbrecht, K., Müller, K., and Leubner-Metzger, G. (2011). First off the mark: early seed germination. J. Exp. Bot. 62, 3289-3309. doi: 10.1093/jxb/err030

Wojtyla, Ł., Garnczarska, M., Zalewski, T., Bednarski, W., Ratajczak, L., and Jurga, S. (2006). A comparative study of water distribution, free radical production and activation of antioxidative metabolism in germinating pea seeds. J. Plant Physiol. 163, 1207-1220. doi: 10.1016/j.jplph.2006.06.014

Worrall, D., Holroyd, G. H., Moore, J. P., Glowacz, M., Croft, P., Taylor, J. E., et al. (2012). Treating seeds with activators of plant defence generates long-lasting priming of resistance to pests and pathogens. New Phytol. 193, 770-788. doi: 10.1111/j.1469-8137.2011.03987.x

Xia, F., Chen, L., Sun, Y., and Mao, P. (2015a). Relationships between ultrastructure of embryo cells and biochemical variations during ageing of oat (Avena sativa L.) seeds with different moisture content. Acta Physiol. Plant. 37, 89. doi: 10.1007/s11738-015-1825-8

Xia, X.-J., Zhou, Y.-H., Shi, K., Zhou, J., Foyer, C. H., and Yu, J.-Q. (2015b). Interplay between reactive oxygen species and hormones in the control of plant development and stress tolerance. J. Exp. Bot. 66, 2839-2856. doi: 10.1093/jxb/erv089

Xin, X., Tian, Q., Yin, G., Chen, X., Zhang, J., Ng, S., et al. (2014). Reduced mitochondrial and ascorbate-glutathione activity after artificial ageing in soybean seed. J. Plant Physiol. 171, 140-147. doi: 10.1016/j.jplph.2013.09.016

Xu, F. J., Jin, C. W., Liu, W. J., Zhang, Y. S., and Lin, X. Y. (2011a). Pretreatment with $\mathrm{H} 2 \mathrm{O} 2$ alleviates aluminum-induced oxidative stress in wheat seedlings. J. Integr. Plant Biol. 53, 44-53. doi: 10.1111/j.1744-7909.2010.01008.x

Xu, J., Yin, H., Yang, L., Xie, Z., and Liu, X. (2011b). Differential salt tolerance in seedlings derived from dimorphic seeds of Atriplex centralasiatica: from physiology to molecular analysis. Planta 233, 859-871. doi: 10.1007/s00425010-1347-y

Yacoubi, R., Job, C., Belghazi, M., Chaibi, W., and Job, D. (2011). Toward characterizing seed vigor in alfalfa through proteomic analysis of germination and priming. J. Proteome Res. 10, 3891-3903. doi: 10.1021/pr101274f
Yao, Z., Liu, L., Gao, F., Rampitsch, C., Reinecke, D. M., Ozga, J. A., et al. (2012). Developmental and seed aging mediated regulation of antioxidative genes and differential expression of proteins during pre- and post-germinative phases in pea. J. Plant Physiol. 15, 1477-1488. doi: 10.1016/j.jplph.2012.06.001

Ye, N., Zhu, G., Liu, Y., Zhang, A., Li, Y., Liu, R., et al. (2012). Ascorbic acid and reactive oxygen species are involved in the inhibition of seed germination by abscisic acid in rice seeds. J. Exp. Bot. 63, 1809-1822. doi: 10.1093/jxb/err336

Yin, X., He, D., Gupta, R., and Yang, P. (2015). Physiological and proteomic analyses on artificially aged Brassica napus seed. Front. Plant Sci. 6:112. doi: 10.3389/fpls.2015.00112

Zhang, D., Chen, L., Li, D., Lv, B., Chen, Y., Chen, J., et al. (2014a). OsRACK1 is involved in abscisic acid- and $\mathrm{H} 2 \mathrm{O} 2$-mediated signaling to regulate seed germination in rice (Oryza sativa, L.). PLoS ONE 9:e97120. doi: 10.1371/journal.pone.0097120

Zhang, Y., Chen, B., Xu, Z., Shi, Z., Chen, S., Huang, X., et al. (2014b). Involvement of reactive oxygen species in endosperm cap weakening and embryo elongation growth during lettuce seed germination. J. Exp. Bot. 65, 3189-3200. doi: $10.1093 /$ jxb/eru167

Zheng, C., Jiang, D., Liu, F., Dai, T., Liu, W., Jing, Q., et al. (2009). Exogenous nitric oxide improves seed germination in wheat against mitochondrial oxidative damage induced by high salinity. Environ. Exp. Bot. 67, 222-227. doi: 10.1016/j.envexpbot.2009.05.002

Conflict of Interest Statement: The authors declare that the research was conducted in the absence of any commercial or financial relationships that could be construed as a potential conflict of interest.

Copyright (c) 2016 Wojtyla, Lechowska, Kubala and Garnczarska. This is an openaccess article distributed under the terms of the Creative Commons Attribution License (CC BY). The use, distribution or reproduction in other forums is permitted, provided the original author(s) or licensor are credited and that the original publication in this journal is cited, in accordance with accepted academic practice. No use, distribution or reproduction is permitted which does not comply with these terms. 